\title{
Therapeutic Potential of Nitazoxanide: An Appropriate Choice for Repurposing versus SARS-CoV-2?
}

Andrew V. Stachulski,* Joshua Taujanskas, Sophie L. Pate, Rajith K. R. Rajoli, Ghaith Aljayyoussi, Shaun H. Pennington, Stephen A. Ward, Weiqian David Hong, Giancarlo A. Biagini, Andrew Owen, Gemma L. Nixon, Suet C. Leung, and Paul M. O’Neill*

Cite This: https://dx.doi.org/10.1021/acsinfecdis.0c00478

ABSTRACT: The rapidly growing COVID-19 pandemic is the most serious global health crisis since the "Spanish flu" of 1918. There is currently no proven effective drug treatment or prophylaxis for this coronavirus infection. While developing safe and effective vaccines is one of the key focuses, a number of existing antiviral drugs are being evaluated for their potency and efficiency against SARS-CoV-2 in vitro and in the clinic. Here, we review the significant potential of nitazoxanide (NTZ) as an antiviral agent that can be repurposed as a treatment for COVID-19.

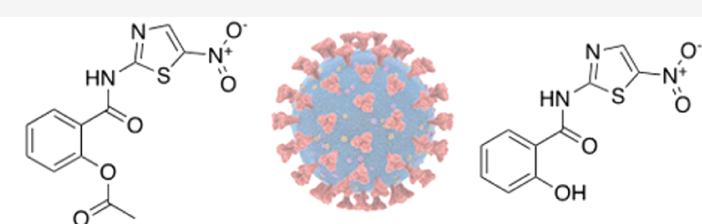

Nitazoxanide (NTZ) $\mathrm{EC}_{50}($ SARS-CoV-2) $=3.16-7.94 \mu \mathrm{M}$
Tizoxanide (TIZ)

$\mathrm{EC}_{50}($ SARS-COV-2) $=3.16 \mu \mathrm{M}$ Originally, NTZ was developed as an antiparasitic agent especially against Cryptosporidium spp.; it was later shown to possess potent activity against a broad range of both RNA and DNA viruses, including influenza A, hepatitis B and C, and coronaviruses. Recent in vitro assessment of NTZ has confirmed its promising activity against SARS-CoV-2 with an $\mathrm{EC}_{50}$ of $2.12 \mu \mathrm{M}$. Here we examine its drug properties, antiviral activity against different viruses, clinical trials outcomes, and mechanisms of antiviral action from the literature in order to highlight the therapeutic potential for the treatment of COVID-19. Furthermore, in preliminary PK/PD analyses using clinical data reported in the literature, comparison of simulated TIZ (active metabolite of NTZ) exposures at two doses with the in vitro potency of NTZ against SARS-CoV-2 gives further support for drug repurposing with potential in combination chemotherapy approaches. The review concludes with details of second generation thiazolides under development that could lead to improved antiviral therapies for future indications.

KEYWORDS: COVID-19, SARS-CoV-2, coronavirus, antiviral, pharmacokinetics, nitazoxanide, tizoxanide

\section{INTRODUCTION}

When reports of a few cases of a new strain of pneumonia caused by an unknown pathogen were reported in Wuhan, a city of central China, in December 2019, there was little international concern. ${ }^{1}$ A few weeks later almost 3000 cases, leading to 81 deaths, had already been recorded in China, and the disease had spread not merely to other areas of Asia but also to Europe, North America, and Australia. ${ }^{2}$ By then the pathogen responsible for cases of pneumonia had been identified as a novel strain of coronavirus, which was named severe acute respiratory syndrome coronavirus 2 (SARS-CoV$2)$, that bears a close resemblance to the severe acute respiratory syndrome (SARS) virus responsible for outbreaks of disease in 2002-2003. ${ }^{3}$ At the time of writing (late November 2020), over 53 million cases of the COVID-19 infection have been reported worldwide with over 1.35 million deaths. ${ }^{4}$

This rapidly growing pandemic is widely regarded as the most serious global health crisis since the "Spanish flu" of 1918. Currently, there is no proven effective small molecule treatment or prophylaxis for the disease although a number of them have been reviewed. ${ }^{5}$ Many groups are actively searching for an effective vaccine and a number of them have entered late stage (phase 3 ) clinical trials with some very positive results as of the end of November 2020.6,7 Early small molecule screening reported by $\mathrm{Wang}^{8}$ revealed several hit molecules in vitro with a focus on the known antiviral remdesivir $(\mathbf{1})^{9,10}$ and the 4-aminoquinoline antimalarial chloroquine (2), ${ }^{11,12}$ which were the main focus of this seminal publication. Subsequently, multiple clinical trials have commenced with remdesivir, chloroquine, and the related hydroxychloroquine (3) ${ }^{13}$ a drug used for autoimmune diseases such as rheumatoid arthritis and systemic lupus erythematosus (Figure 1).

In this review, we concentrate on the significant potential of nitazoxanide, 2-(acetyloxy)- $\mathrm{N}$-(5-nitro-2-thiazolyl) benzamide (NTZ, 4), as a broad spectrum antiviral agent against COVID19. NTZ, initially developed as an antiparasitic agent especially

Special Issue: Antiviral Therapeutics

Received: July 8, 2020 

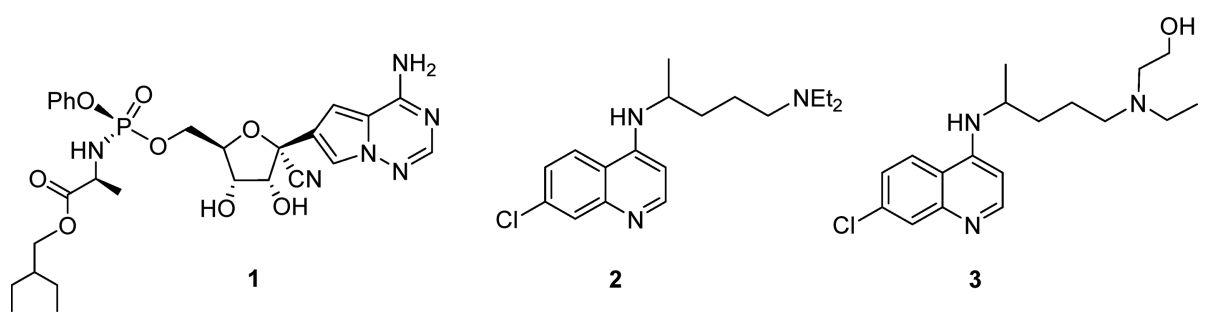

Figure 1. Structures of remdesivir (1), chloroquine (2), and hydroxychloroquine (3).

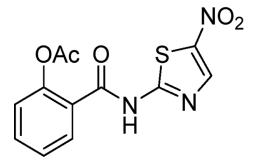

4

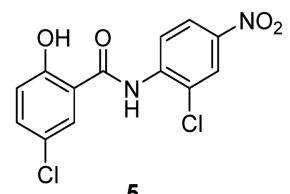

5

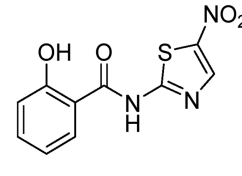

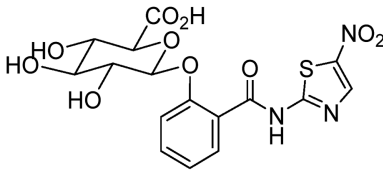

6a

Figure 2. Structures of nitazoxanide (NTZ) (4), niclosamide (5), tizoxanide (TIZ) (6) and tizoxanide glucuronide (TG) (6a).

Table 1. Physiochemical Properties of NTZ and TIZ ${ }^{a}$

$\begin{array}{lccccccccc} & \mathrm{HBD} & \mathrm{HBA} & \mathrm{p} K_{\mathrm{a}}^{21,25} & \mathrm{p} K_{\mathrm{a}} \text { (strongest acidic) } & \mathrm{p} K_{\mathrm{a}} \text { (strongest basic) } & \log \mathrm{P} & \log \mathrm{D} & \operatorname{LogS}(\mathrm{pH} 7.4) & \text { human protein binding (\% bound) })^{15,30} \\ \text { NTZ } & 1 & 8 & 6.18 & 8.3 & -4.2 & 2.322 & 2.322 & 2.601 & >99.9 \\ \text { TIZ } & 2 & 7 & & 7.81 & -4.2 & 2.157 & 2.157 & 2.85 & \end{array}$

${ }^{a}$ Values for HBD, HBA, $\log \mathrm{P}, \log \mathrm{D}$, and $\log S$ were calculated or predicted by StarDrop (version 6.5). Values for $\mathrm{p} K_{\mathrm{a}}$ (strongest acidic) and $\mathrm{p} K_{\mathrm{a}}$ (strongest basic) were predicted by Chemaxon via DrugBank. ${ }^{20}$

against Cryptosporidium spp., ${ }^{14}$ was later shown to have broadspectrum antiviral activity ${ }^{15,16}$ including activity against influenza A (Figure 2). In a recent SARS-CoV-2 screening publication by Wang and co-workers, NTZ was somewhat overlooked despite expressing a similar antiviral $\mathrm{EC}_{50}$ to chloroquine. Here, we summarize and analyze the current literature on NTZ, on which there is a large body of clinical data, and related thiazolides with a recommendation that trials of this agent either alone or in combination as a curative agent for COVID-19 are warranted.

\section{AN APPROVED CRYPTOSPORIDIUM DRUG WITH BROAD ANTI-INFECTIVE SPECTRA}

NTZ (4) was first synthesized in the early 1970s and is a prototype of a class of compounds known as the thiazolides. $^{15,16}$ Its structure is based on the scaffold of the anthelmintic niclosamide (5), which also displays broad spectrum antiviral activity including against coronaviruses $\left(\mathrm{IC}_{50}\right.$ of $0.28 \mu \mathrm{M}$ versus SARS-CoV-2) (Figure 2). ${ }^{15,17,18}$ In vivo, the active form of NTZ is known as tizoxanide (TIZ, 6) (in vitro against SARS CoV-2 NTZ and TIZ have similar potencies, vide infra) and together with niclosamide represent the potential of salicylamide derivatives to be developed as a class of compounds against SARS-CoV-2 (an overview of niclosamide is outside the scope of this review). ${ }^{19}$

The main indication of NTZ is as an oral antiparasitic agent, and it is registered in Latin America, Egypt, India, and Bangladesh for the treatment of intestinal protozoa and helminths. In addition to this, NTZ is FDA-approved in the US for the treatment of diarrhea caused by Cryptosporidium parvum and Giardia intestinalis. ${ }^{15}$ Today it remains the only FDA-approved treatment for Cryptosporidium infections. ${ }^{15,16}$ Currently, NTZ is available orally both as a tablet $(500 \mathrm{mg}$ ) and in the form of a suspension $(100 \mathrm{mg} / 5 \mathrm{~mL})$ [AliniaRomark] for the treatment of adults and pediatric patients, respectively. $^{20,21}$ In addition to NTZ's key role as an antiparasitic, it has shown promising activity as a broad spectrum antibacterial and antiviral agent (vide infra). ${ }^{22}$ Over the years, NTZ has been involved in more than 40 clinical trials across a broad range of drug targets, highlighting its multifunctional chemotherapeutic significance. ${ }^{20}$

Reports of NTZ's remarkable broad-spectrum antibacterial activity first began to appear in the 1990s. ${ }^{23}$ Over the past two decades, numerous studies and clinical trials have confirmed its activity across a wide variety of both Gram-negative and Grampositive anaerobic bacteria. ${ }^{15}$ More recently, studies have revealed its activity against Gram-positive aerobic bacteria such as Mycobacterium tuberculosis, in addition to a number of Gram-negative aerobes. ${ }^{15,24}$ There is great speculation surrounding the mechanisms of action of NTZ. Both its antiprotozoal and anaerobic antibacterial activity are believed to be as a result of its ability to inhibit pyruvate:ferredoxin oxidoreductase (PFOR), an enzyme essential for anaerobic energy metabolism. ${ }^{15,25}$ In the case of aerobic bacteria there is strong evidence to suggest that NTZ acts as an uncoupler, disrupting membrane potential and intraorganism $\mathrm{pH}$ homeostasis. $^{15,26}$

It was also in the late 1990s that the antiviral activity of NTZ was discovered by serendipity during its use in the treatment of AIDS patients who had developed cryptosporidiosis. ${ }^{27}$ Since then reports have emerged confirming its activity against a broad range of both RNA and DNA viruses, including influenza A, influenza B, respiratory syncytial virus, parainfluenza, coronavirus, rotavirus, norovirus, hepatitis $B$, hepatitis $C$, dengue, yellow fever, Japanese encephalitis virus, and human immunodeficiency virus. ${ }^{15,28,29}$ (see later section).

Overall, the oral bioavailability of the thiazolide class of compounds is generally quite poor due to low aqueous solubility. ${ }^{19}$ NTZ has an aqueous solubility of $0.0075 \mathrm{mg} / \mathrm{mL}$ and an absolute oral bioavailability of just $3 \%$ in the rat. ${ }^{19-21}$ As a prodrug, NTZ is partially absorbed from the gastrointestinal tract and rapidly hydrolyzed into the active form of 
Table 2. Summary of $\mathrm{EC}_{50}, \mathrm{IC}_{50}$, and $\mathrm{IC}_{90}$ Values for Key Indications of NTZ and TIZ

\begin{tabular}{|c|c|c|c|c|}
\hline virus & strain & NTZ EC 50 or $\mathrm{IC}_{50}(\mu \mathrm{M})$ & $\mathrm{TIZ} \mathrm{EC}_{50}$ or $\mathrm{IC}_{50}(\mu \mathrm{M})$ & ref \\
\hline \multirow[t]{2}{*}{ rotavirus } & SA-11 & 3.3 & 1.9 & Rossignol et al., ${ }^{44}$ La Frazia et al. ${ }^{46}$ \\
\hline & WA-G1P & 6.5 & 3.8 & La Frazia et al. ${ }^{46}$ \\
\hline hepatitis B & wild-type & $0.12,^{a} 0.59^{b}$ & $0.15,^{a} 0.46^{b}$ & Korba et $\mathrm{al}^{48}$ \\
\hline \multirow[t]{3}{*}{ hepatitis C } & genotype 1a & 0.33 & 0.25 & Korba et al. ${ }^{48}$ \\
\hline & genotype $1 \mathrm{~b}$ & 0.21 & 0.15 & Korba et al. ${ }^{48}$ \\
\hline & $1 \mathrm{a}, 1 \mathrm{~b}, 2 \mathrm{a}, 4 \mathrm{a}$ & 2.5 to $>10.1$ & 2.7 to $>8.8$ & Khan et al. ${ }^{49}$ \\
\hline \multirow[t]{6}{*}{ influenza A } & $\mathrm{H} 1 \mathrm{~N} 1 \mathrm{~A} / \mathrm{PR} / 8 / 34$ & 3.3 & 3.8 & Rossignol et al. ${ }^{61}$ \\
\hline & H1N1 A/WSN/33 & 1.6 & 1.9 & Rossignol et al. ${ }^{61}$ \\
\hline & H5N9 A/Ck/It/9097/97 & 3.3 & 1.9 & Rossignol et al. ${ }^{61}$ \\
\hline & $\mathrm{H} 3 \mathrm{~N} 2 \mathrm{v}$ (4 variants) & $0.88-18.3^{c}$ & & Sleeman et al. ${ }^{62}$ \\
\hline & H1N1 (54 variants) & & $0.13^{d}$ & Tilmanis et al. ${ }^{63}$ \\
\hline & H3N2 (53 variants) & & $0.16^{d}$ & Tilmanis et al. ${ }^{63}$ \\
\hline \multirow[t]{2}{*}{ influenza B } & Victoria lineage (47 variants) & & $0.18^{d}$ & Tilmanis et al. ${ }^{63}$ \\
\hline & Yamagata lineage (56 variants) & & $0.16^{d}$ & Tilmanis et al. ${ }^{63}$ \\
\hline \multirow[t]{5}{*}{ coronavirus } & CCov S-378 & 3.3 & & Rossignol $^{15}$ \\
\hline & murine coronavirus & 3.3 & & Cao et al. ${ }^{70}$ \\
\hline & MERS-CoV & 3.0 & 3.1 & Rossignol $^{28}$ \\
\hline & SARS-CoV-2 & 2.12 & & Wang et al. ${ }^{8}$ \\
\hline & SARS-CoV-2 & $3.16-7.94$ & 3.16 & $\mathrm{NIH}^{71}$ \\
\hline
\end{tabular}

the drug, tizoxanide (TIZ, 6) (Figure 2), ${ }^{30}$ which is heavily protein bound (Table 1). ${ }^{15}$ As a result, coadministration with other highly protein bound drugs, such as warfarin, may be a concern. A phase I study into the effect of NTZ on the pharmacodynamics and pharmacokinetics of a single dose of warfarin concluded it to be safe and well tolerated. ${ }^{31}$ It is not fully understood as to how or why TIZ is so highly plasma protein bound, but it is believed to primarily bind to albumins due to being slightly acidic (Table 1 ). ${ }^{32}$

Over the past two decades NTZ has been subjected to extensive pharmacological testing for its safety in both animals and humans. ${ }^{15}$ Its use has been evaluated in a number of clinical trials with only minor adverse effects such as diarrhea, abdominal pain, headache, and nausea being reported at low rates similar to placebo groups. ${ }^{33,34}$ Additionally, in vitro metabolic studies have demonstrated that there is no significant inhibitory effect on cytochrome P450 (CYP450) enzymes; therefore no drug-drug interactions are expected. ${ }^{35}$ Overall, NTZ has an established safety profile, with one-time oral doses of up to a remarkable $4 \mathrm{~g}$ shown to be safely tolerated in healthy adult volunteers. ${ }^{36}$

\section{THE ANTIVIRAL SPECTRA AND ANTI-CORONAVIRUS ACTIVITIES OF NTZ: IN VITRO, IN VIVO, AND CLINICAL}

As noted, NTZ and its active metabolite, TIZ, along with newer thiazolide analogues, have been shown to exhibit broadspectrum activity against a wide range of viruses. ${ }^{15,37,38}$ The most significant indications have been those against intestinal viruses, hepatitis, and influenza. Key in vitro and clinical data for NTZ against these indications is summarized in Table 2 and Table 3 respectively. Other reports indicate significant in vitro activity against a host of viral species as described later. $^{39-43}$

The antiviral activity of NTZ was first reported against rotavirus by Rossignol et al. in 2006. ${ }^{44}$ This study included in vitro assays of TIZ in cells infected with simian rotavirus SA11. It was found that TIZ inhibited rotavirus replication with an $\mathrm{EC}_{50}$ of $1.9 \mu \mathrm{M}$ and that this effect was sustained with increasing viral load (Table 2). Also reported was a randomized double-blind placebo-controlled trial of 50 children with rotavirus diarrhea who were treated with either NTZ or placebo. NTZ treatment was shown to decrease the median time to resolution of symptoms to $31 \mathrm{~h}$, with no adverse effects reported, compared to $75 \mathrm{~h}$ for the placebo group (Table 3). Further clinical trials in adults demonstrated that NTZ treatment significantly reduced the median time to resolution of symptoms of both rotavirus and norovirus related gastroenteritis to 1.5 days, compared to 2.5 days for placebo (Table 3). ${ }^{45}$ The clinical findings were corroborated by further in vitro studies against rotavirus, ${ }^{46}$ showing that NTZ and TIZ inhibited viral replication in both the simian SA11-G3P rotavirus $\left(\mathrm{EC}_{50}\right.$ of $3.3 \mu \mathrm{M}$ and $1.9 \mu \mathrm{M}$ respectively) and human Wa-G1P rotavirus $\left(\mathrm{EC}_{50}\right.$ of $6.5 \mu \mathrm{M}$ and $3.8 \mu \mathrm{M}$ respectively). Both compounds also demonstrated significant cytoprotective effects in cells infected with rotavirus. Recent in vitro studies have also confirmed the dose-dependent activity of NTZ and TIZ against norovirus with no major cytotoxicity observed. $^{47}$

NTZ and TIZ are also active against hepatitis B virus (HBV), inhibiting the production of both extracellular HBV DNA $\left(\mathrm{EC}_{50}\right.$ of $0.12 \mu \mathrm{M}$ and $0.15 \mu \mathrm{M}$, respectively) and intracellular $\mathrm{HBV}$ replicons $\left(\mathrm{EC}_{50}\right.$ of $0.59 \mu \mathrm{M}$ and $0.46 \mu \mathrm{M}$, respectively) with good selectivity and low cytotoxicity. ${ }^{48}$ Similar results were obtained against replicating hepatitis $\mathrm{C}$ virus (HCV), with $\mathrm{EC}_{50}$ values of $0.33 \mu \mathrm{M}$ for NTZ and 0.25 $\mu \mathrm{M}$ against $\mathrm{HCV}$ genotype $1 \mathrm{a}^{48}$ For both $\mathrm{HBV}$ and $\mathrm{HCV}$, antiviral activity was maintained across multiple genotypes (Table 2). These results have been corroborated in later screens along with novel thiazolide analogues. ${ }^{27,29}$ However, in the case of $\mathrm{HCV}$, other studies using alternative detection methods (qRT-PCR) have not consistently replicated this in vitro activity. ${ }^{49}$ Further studies also demonstrated that both NTZ and TIZ possessed a high barrier to resistance by $\mathrm{HCV}^{50,51}$ A number of clinical trials have also been conducted, investigating the efficacy of NTZ treatment of both hepatitis B and C. Trials against hepatitis B have been somewhat limited, comprising case reports ${ }^{52}$ and a small 


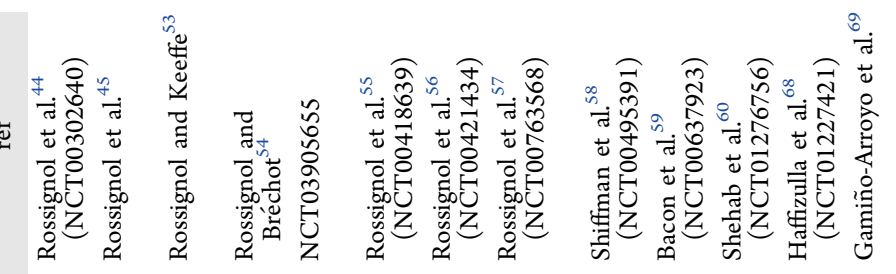
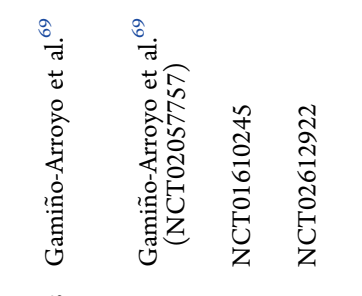

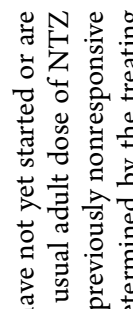
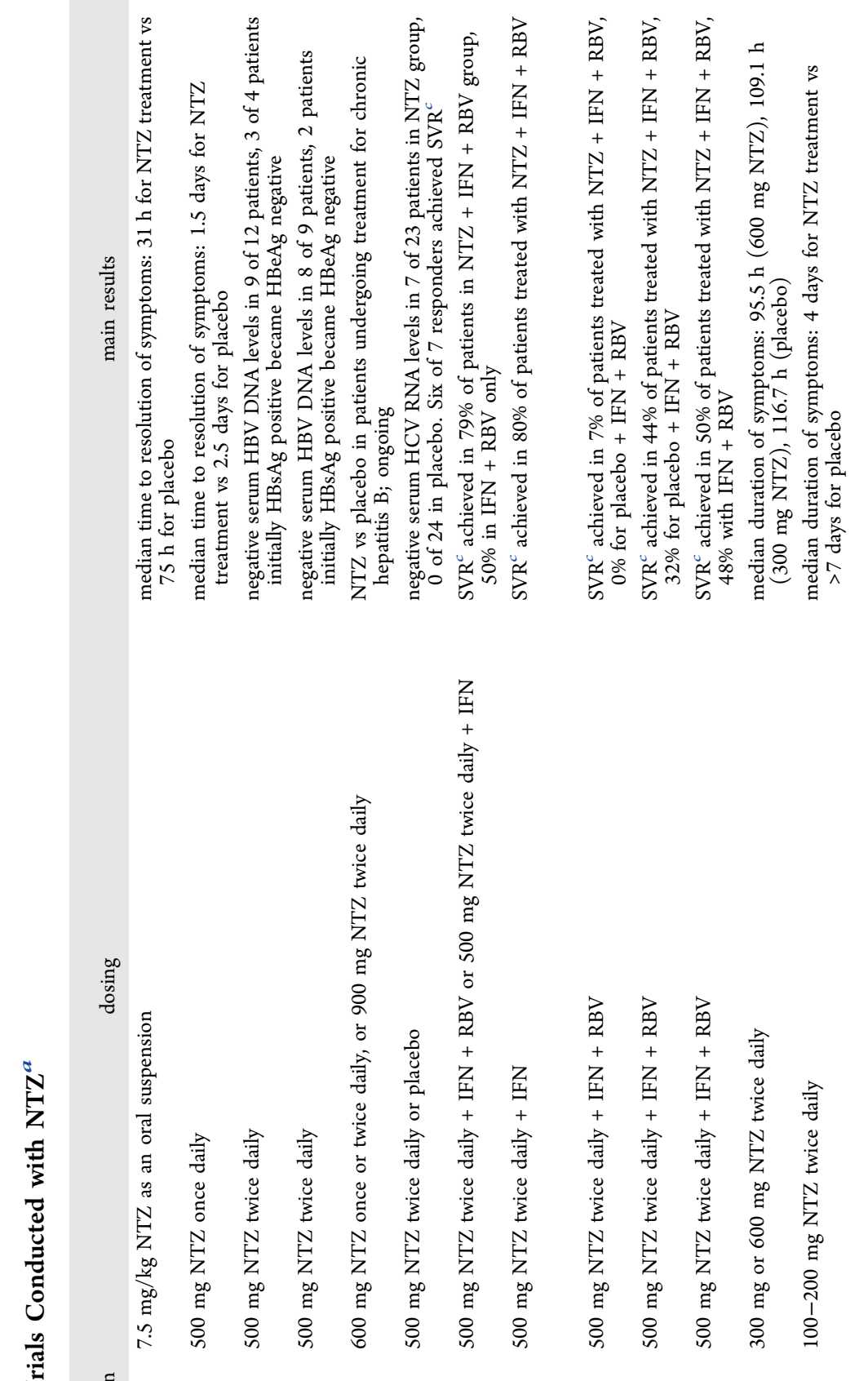

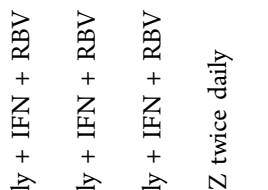

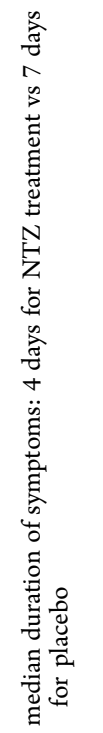

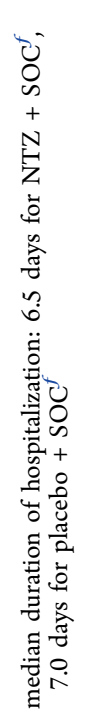

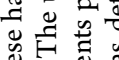

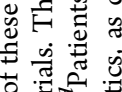

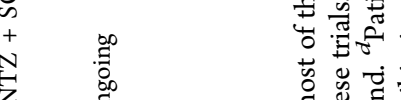

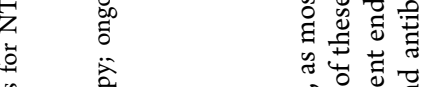

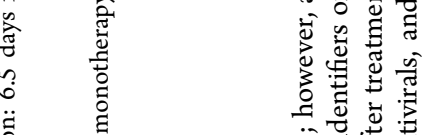

至

官苋苋

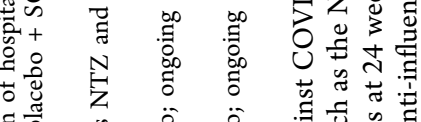

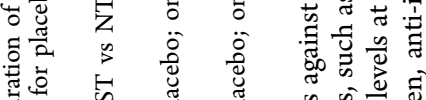

की

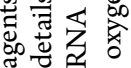

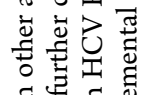

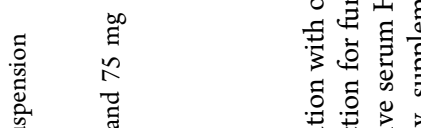

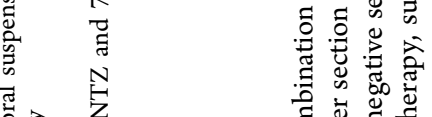

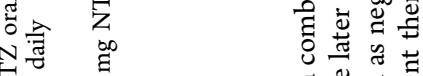

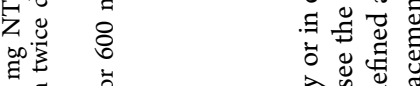

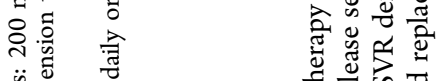

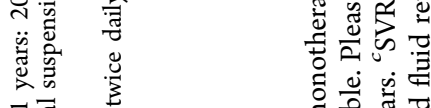

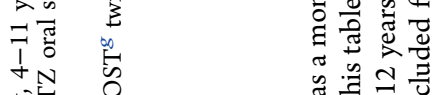

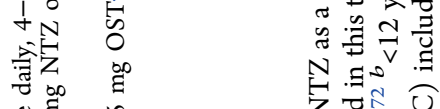

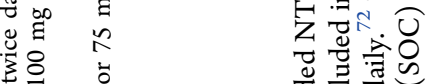

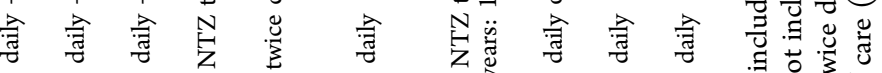

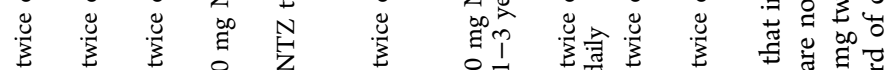

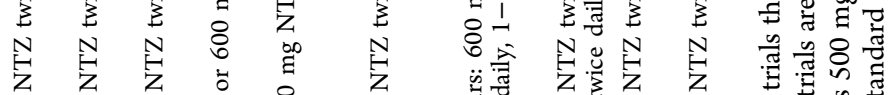

b b b b o b

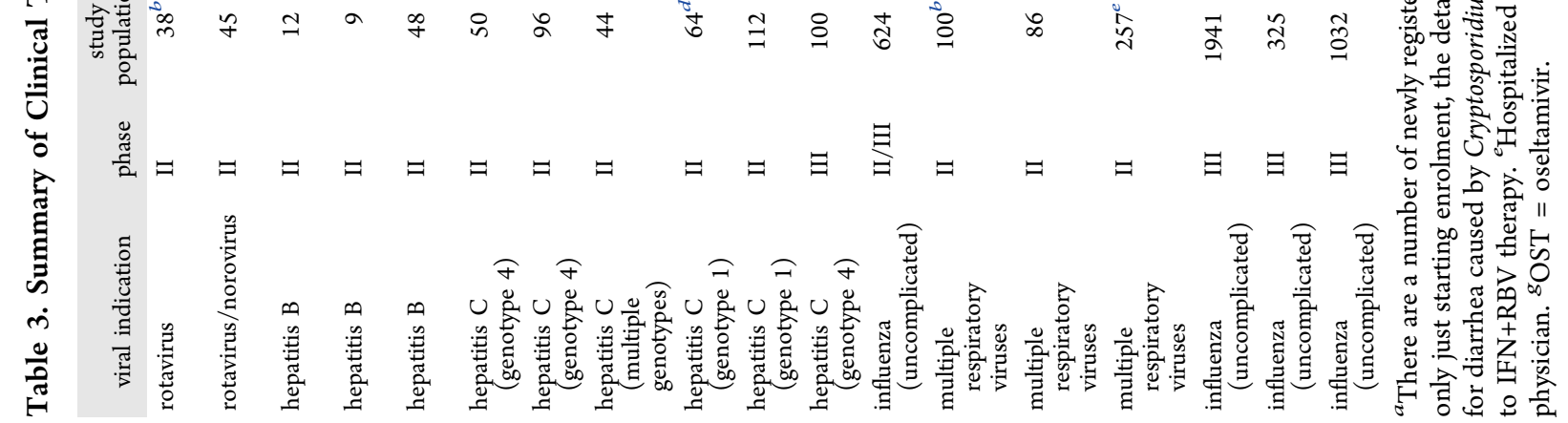


clinical trial ${ }^{53,54}$ in adults with chronic hepatitis B (Table 3). Across the two clinical trials, reductions of serum HBV DNA to undetectable levels were observed in most patients $(81 \%$ overall), as well as several patients who initially tested positive for hepatitis $\mathrm{B}$ e antigen ( $\mathrm{HBeAg}$ ) becoming $\mathrm{HBeAg-negative}$ (5 out of 6 patients total) over the treatment period. Furthermore, 29\% of patients also tested negative for hepatitis B surface antigen ( $\mathrm{HBsAg}$ ) at the end of treatment (Table 3).

Additional trials are ongoing to assess coadministration of NTZ with existing regimens for treatment of chronic HBV (NCT03905655) (Table 3). Clinical trials against hepatitis C have demonstrated that NTZ has modest efficacy as a monotherapy at the doses at which it has been tested, achieving undetectable serum HCV RNA in 7 out of 23 patients in the treatment group compared to 0 of 24 in the placebo group. ${ }^{55}$ Subsequent trials examined the effect of coadministration of NTZ with Peginterferon alfa-2a (IFN) and ribavirin (RBV) in various regimens in 96 patients with chronic hepatitis $C .{ }^{56,57}$ The results indicated that NTZ coadministered with RBV and IFN increased the rate of rapid viral response (64\%) and sustained viral response (79\%) compared to RBV and IFN only ( $38 \%$ and $50 \%$, respectively). Further, two large trials (176 patients) demonstrated an increase in sustained viral response for the combined treatment compared to placebo plus RBV and IFN ( $7 \%$ and $44 \%$ for combined treatment compared to $0 \%$ and $32 \%$ for placebo group). ${ }^{58,59}$ However, later clinical trials have failed to replicate these results, reporting no benefit for the addition of NTZ to IFN and RBV for treatment of hepatitis C. ${ }^{60}$

Influenza has become another important viral target for NTZ, with early studies reporting significant in vitro activity of both NTZ and TIZ against several strains of influenza A virus (IAV) including H1N1, H3N2, and H5N9 (Table 2). ${ }^{61}$ This study demonstrated that NTZ and TIZ exhibited dosedependent activity versus IAV in a variety of cell types, with $\mathrm{EC}_{50}$ values of $1.7-5.7 \mu \mathrm{M}$ (Table 2). NTZ was subsequently tested against a panel of H3N2 IAV variants circulating in the United States between 2011 and 2013, ${ }^{62}$ reporting slightly higher activity with $\mathrm{IC}_{90}$ values between 1.1 and $5.7 \mu \mathrm{M}$. These findings were expanded upon with a screen of 210 circulating IAV and influenza B virus (IBV) strains against TIZ. ${ }^{63}$ The results were in line with previous studies, with median $\mathrm{EC}_{50}$ values of $0.48 \mu \mathrm{M}$ and $0.62 \mu \mathrm{M}$ against H1N1 and H3N2 IAV strains, respectively, and $0.66 \mu \mathrm{M}$ and $0.60 \mu \mathrm{M}$ against Victoria lineage and Yamagata lineage IBV. Further in vitro studies showed this activity was also present against canine influenza virus with comparable potency $\left(\mathrm{EC}_{50}=1.63 \mu \mathrm{M}\right.$ and $1.89 \mu \mathrm{M}$ for both NTZ and TIZ, respectively). ${ }^{64}$ In vitro studies with oseltamivir and zanamivir have also demonstrated potential for use of NTZ as a combination therapy. ${ }^{65}$ Once more, NTZ demonstrated significant activity against a number of strains of IAV ( $\mathrm{IC}_{50}$ values between 1.0 and $3.2 \mu \mathrm{M}$ ) as well as synergistic effects with both oseltamivir and zanamivir, compared to individual administration of each compound. NTZ has also emerged as one of 41 hits from a screen of 1280 compounds against IAV, ${ }^{66}$ as well as being identified in a screen for potential protein disulfide isomerase inhibitors of IAV/IBV. ${ }^{67}$ A number of clinical trials have been conducted for NTZ treatment of influenza based on its significant in vitro activity. A phase $2 \mathrm{~b} / 3$ trial on 624 patients conducted in the United States found that individuals with uncomplicated influenza-like illness experienced a significant reduction in time to alleviation of symptoms at high doses (median reduction of
$21.2 \mathrm{~h}$ at $600 \mathrm{mg} /$ day, Table 3) compared to placebo, although the reduction at the lower dose (median reduction of $7.6 \mathrm{~h}$ at $300 \mathrm{mg} /$ day) was not statistically significant. ${ }^{68}$ Trials in children with influenza-like illness in Mexico (186 children across 2 studies) demonstrated that NTZ treatment reduced time to resolution of symptoms by 3 days. ${ }^{69}$ This was followed by a trial in 257 patients who had been hospitalized with severe influenza-like illness (caused by a variety of viruses including influenza), which found no statistically significant reduction in duration of hospital stay associated with NTZ plus standard of care (including fluid replacement therapy, supplemental oxygen, antivirals, and antibiotics) compared to placebo plus standard of care. ${ }^{69}$ A number of further large phase 3 trials are ongoing (NCT01610245, NCT02612922, NCT03336619) to further determine the role of NTZ in influenza therapy.

Early testing of the antiviral properties of NTZ and other analogues revealed high activity against canine coronavirus (CCov, $\left.\mathrm{IC}_{50}=5.2-21.2 \mu \mathrm{M}\right)$ among a wide range of other coronaviruses (Table 2). ${ }^{15,38}$ Following the 2012 Middle East respiratory syndrome (MERS) outbreak, screening of the NIH clinical collection identified NTZ as a potent inhibitor of murine coronavirus $\left(\mathrm{IC}_{50}=3.3 \mu \mathrm{M}\right.$, Table 2) and was recommended as a potential therapy for the disease. ${ }^{70}$ Direct screening of TIZ and NTZ against MERS-CoV also showed high activity with $\mathrm{IC}_{50}$ values of $3.1 \mu \mathrm{M}$ and $3.0 \mu \mathrm{M}$, respectively. ${ }^{28}$ Most recently, NTZ was also reported to be active against SAR-CoV-2 in vitro (see later section). In general, TIZ showed either equal or slightly higher potency than NTZ in most of the reported antiviral assays.

\section{IN VITRO ACTIVITY OF NTZ AND ITS METABOLITES AGAINST SARS-COV-2}

Only one published paper to date has been reported by Wang et al. for the in vitro activity of NTZ against SARS-CoV-2 with no data for the major metabolite TIZ. ${ }^{\circ}$ The reported $\mathrm{EC}_{50}$ was $2.12 \mu \mathrm{M}(0.651 \mu \mathrm{g} / \mathrm{mL})$ for NTZ against SARS-CoV-2 (BetaCoV/Wuhan/WIV04/2019) in Vero E6 cells. In another recent report, ${ }^{73}$ after reanalysis of the data from the same study reported by Wang et al., the $\mathrm{EC}_{90}$ of NTZ was estimated as $4.65 \mu \mathrm{M}(1.43 \mu \mathrm{g} / \mathrm{mL})$. It is well documented in the literature that NTZ is readily turned over to its active metabolite TIZ in vivo ( $\mathrm{NTZ}$ in vivo $t_{1 / 2} \leq 6 \mathrm{~min}$ ) and $\mathrm{NTZ}$ is undetectable in plasma. ${ }^{30}$ However, the turnover rates of NTZ to TIZ in vitro could vary significantly under different temperature and $\mathrm{pH}$ conditions, for example, the half-life of NTZ at $37{ }^{\circ} \mathrm{C}$ was $33 \mathrm{~h}$ at $\mathrm{pH} 5$ and only $3 \mathrm{~h}$ at $\mathrm{pH}$. Under the assay conditions, it is fair to say that the dynamic ratio of NTZ/TIZ within the reported assay could lead to a misinterpretation of the in vitro activity of either NTZ or TIZ against the virus in vitro. So, it is critically important that the active metabolite, TIZ, is assessed in any antiviral assay against SARS-CoV-2 to determine the potency unambiguously. Most recently, from a non-peerreviewed source, the potency of TIZ against SARS-CoV-2 in vitro $\left(\mathrm{EC}_{50}=3.16 \mu \mathrm{M}\right)$ was reported as similar to $\mathrm{NTZ}\left(\mathrm{EC}_{50}\right.$ $=3.16-7.94 \mu \mathrm{M})$ under the same assay conditions. ${ }^{71}$ These data again confirmed that both NTZ and TIZ are active against SARS-CoV-2 at a low micromolar range in vitro (we have evaluated the antiviral activity independently at Liverpool with $\mathrm{EC}_{50}$ values of $5.05 \mu \mathrm{M}$ and $4.07 \mu \mathrm{M}$ for NTZ and TIZ, respectively, which ties in with literature observations (See Supporting Information, Figure S1). Furthermore, as described in the following section (Human PK analysis), tizoxanide glucuronide (TG) (Figures 2, 6a), the major metabolite of 


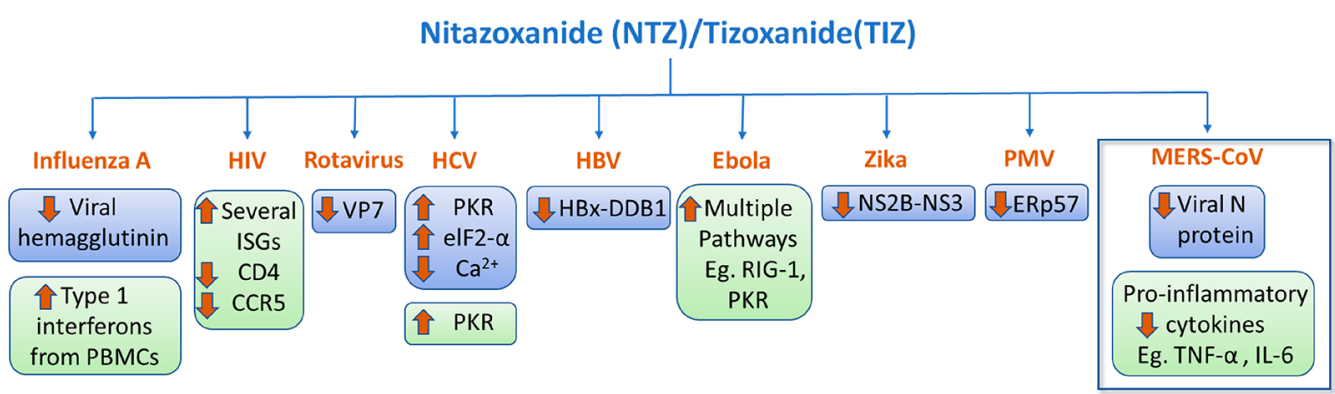

\begin{tabular}{|c|c|}
\hline KEY: & \\
\hline Viral response & ن upregulation \\
\hline Host immunological response & $\checkmark$ downregulation \\
\hline
\end{tabular}

Figure 3. Summary of viral modes of action of NTZ/TIZ.

TIZ, is another major circulating species metabolite after oral administration of NTZ in human; the in vitro activity of TG against the virus is yet another important factor to be considered when considering the overall antiviral efficacy of NTZ in humans but to date the activity of this metabolite has not been formally measured.

\section{MECHANISM OF ANTIVIRAL EFFECTS}

With NTZ's demonstrated efficacy and clinical utility against a wide range of viral infections, its potential role in the treatment of SARS-CoV-2 has come into focus. Studies into the mode of action of NTZ within the different viral infections have identified significant upregulation of innate immune responses in many cases indicative of NTZ targeting one or more host factors. Specific effects on the virus have also been identified potentially due to secondary host immunomodulatory events or even direct drug action. NTZ's broad spectrum of antiviral activity is indicative of the former, but further investigations are required to definitively establish this (Figure 3). The variability of nitazoxanide's antiviral mode of action against different viruses indicates that this area requires further studies to clarify both mechanism and mode of action and to exclude nonspecific effects, such as those caused by pan-assayinterference (PAINS) properties. $^{74,75}$ While nitazoxanide has not been reported to act as an assay interference compound in the literature, is inert in chemical reactivity screens, and is not reported to be an aggregator, ${ }^{76}$ the unusually broad spectrum of activity requires more definitive studies to define common and differential targets against its target viruses.

As noted, NTZ is also known to have antiparasitic activity against Giardia lamblia and Cryptosporidium parvum. NTZ is the mainstay of proven treatment against Cryptosporidium infections; however it is not effective in severely immunocompromised patients, further indicating NTZ's role in immunomodulation of the host to impart pathogen clearance. ${ }^{77}$ While the focus of this review is NTZ's antiviral activity, this adds to the weight of evidence toward the immunomodulatory mode of action of NTZ. The disease specific information included below summarizes what is known within the literature, but it should be stressed that there is much that is still unknown.

In the case of influenza $\mathrm{A}$, it has been shown through in vitro cellular cultures (PR8-infected MDCK cells) that NTZ mediates reduced maturation of viral hemagglutinin at the post-translational stage after entry into the cell, between the endoplasmic reticulum and the Golgi apparatus. ${ }^{15,16}$ Intracellular transport and insertion into host plasma membrane are both impaired as a result. NTZ has been shown to have no effect on the other glycoprotein, neuraminidase, the target of oseltamivir and zanamivir, or the M2 protein, the target of amantadine, and it had no effect on viral infectivity, adsorption, or entry into target cells as determined by in vitro studies utilizing SA11-infected MA104 cells. ${ }^{46,61}$

NTZ also has effects in peripheral blood mononuclear cells (PBMCs). PBMCs from 10 healthy donors were cultured in the presence or absence of 3 different doses of TIZ $(0.5,1.0$, and $10 \mathrm{mg} / \mathrm{mL}$ ) in both unstimulated and flu-stimulated conditions and analyzed for $\mathrm{T}$ helper and cytotoxic $\mathrm{T}$ lymphocyte (CTL) activity as well as for toll-like receptor 7 (TLR7) and TLR8 expression and type I interferon (IFN) responses. NTZ potentiates the production of type 1 interferons (alpha and beta) produced by the host's fibroblasts. ${ }^{78}$ The full significance of this is not clearly defined, but it may contribute to the antiviral activity of NTZ by interfering with maturation of the hemagglutinin glycoprotein as detailed above or as another secondary mechanism of action. Similar effects have been seen during in vitro HIV-1 studies utilizing PBMCs from 20 healthy donors infected in vitro with $\mathrm{HIV}-1_{\mathrm{BaL}}$, where NTZ activates an innate immune response with the up-regulation of several interferonstimulated genes (ISGs), including those involved in the cholesterol pathway, particularly the cholesterol-25 hydroxylase $(\mathrm{CH} 25 \mathrm{H})$. NTZ inhibition of $\mathrm{HIV}-1$ replication in vitro could be due to its ability to stimulate potent and multifaceted antiviral immune responses. ${ }^{39,40,79}$ NTZ has also been shown to decrease HIV-1 replication in monocyte-derived macrophages (MDMs) if present before or during HIV-1 infection. This NTZ effect is associated with downregulation of HIV-1 receptors $\mathrm{CD} 4$ and $\mathrm{CCR} 5$ and increasing gene expression of host cell anti-HIV resistance factors APOBEC3A/3G and tetherin.

TIZ has been studied to ascertain its mode of action in rotavirus. In vitro studies have demonstrated that TIZ inhibits the maturation of rotavirus viral protein 7 (VP7, a glycoprotein that forms the outer part of the virion and one of the six structural glycoproteins involved in rotavirus replication), alters viroplasm formation, and interferes with viral morphogenesis by hindering the interaction between the nonstructural proteins NSP5 and NSP2. ${ }^{46}$

With HCV in cell cultures, TIZ has been shown to activate protein kinase $\mathrm{R}$ (PKR). PKR plays an important role in the innate immune response. PKR is activated in cells exposed to double-stranded RNA, which subsequently results in phos- 


\section{Exposure to $\mathrm{TIZ}[\mu \mathrm{g} / \mathrm{mL}] \longrightarrow$ Plasma Exposure $\longrightarrow$ Lung Exposure}

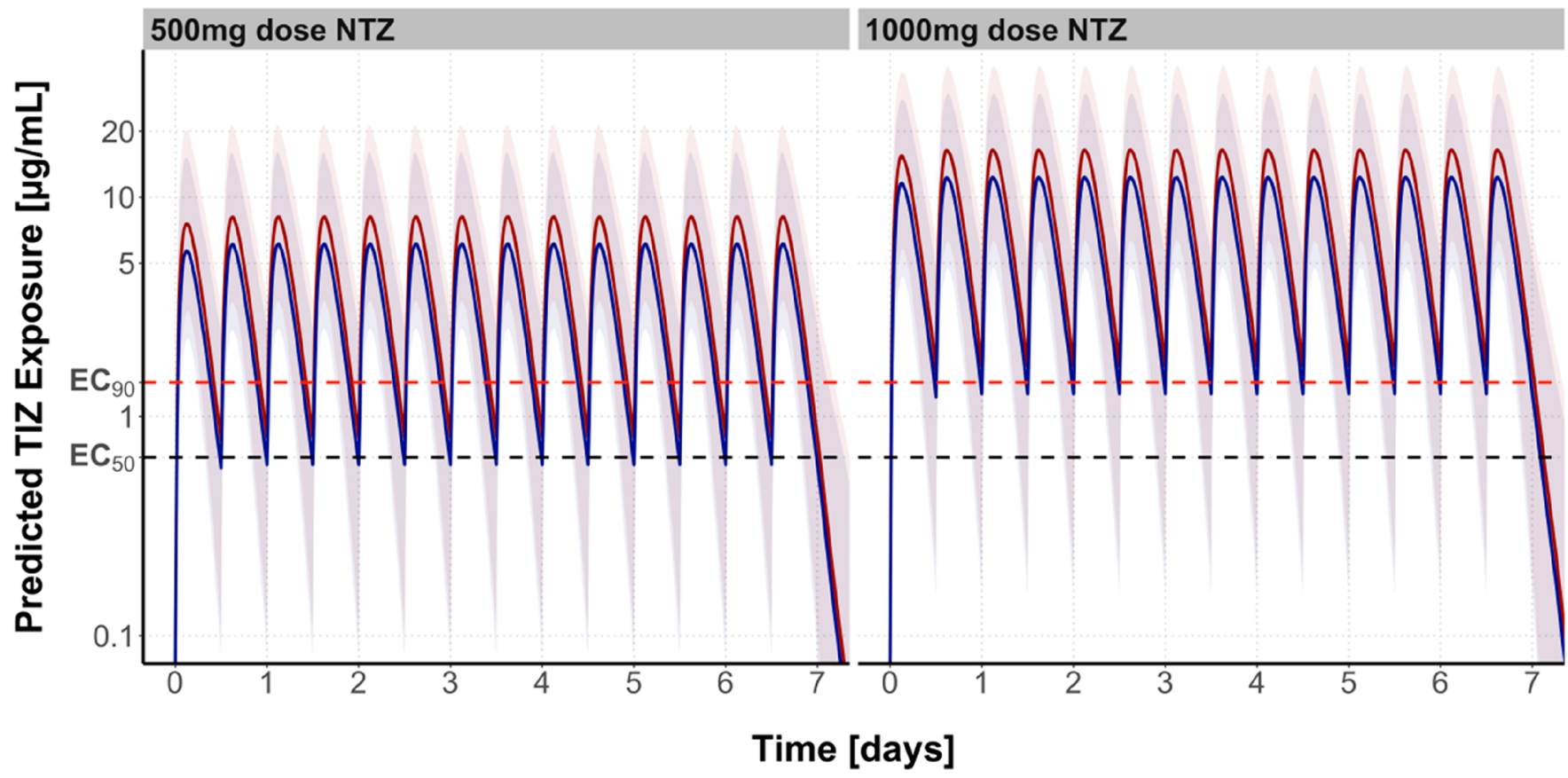

Figure 4. Comparison of simulated TIZ exposures at two doses with the in vitro potency of NTZ against SARS-CoV-2. Simulated plasma (red) and lung (blue) exposures of TIZ after receiving 0.5 or $1.0 \mathrm{~g}$, bid, dose of NTZ for 7 days. The dashed lines represent the in vitro $\mathrm{EC}_{50}(0.641 \mu \mathrm{g} / \mathrm{mL})$ and $\mathrm{EC}_{90}(1.43 \mu \mathrm{g} / \mathrm{mL})$ levels. Simulation was based on fitting data reported in Stockis et al. ${ }^{91}$ in fed volunteers to a one-compartment metabolite formation model.

phorylation of eukaryotic initiation factor $2 \alpha$ (eIF2- $\alpha$ ), a gene known to block viral replication. ${ }^{53,80,81}$ TIZ therefore has the potential to boost intracellular host antiviral activity.

In vitro studies using bovine viral diarrhea virus (BVDV) in MDBK cells as a surrogate for HCV infection have shown that NTZ inhibits replication of cytopathic and noncytopathic BVDV by a mechanism that is likely to involve phosphorylation of PKR and eIF2- $\alpha$. NTZ was also found to deplete ATP-sensitive intracellular $\mathrm{Ca}^{2+}$ stores resulting in mild endoplasmic reticulum (ER) stress; this in turn disrupts $N$ linked glycosylation of BVDV structural proteins. ${ }^{82}$ NTZ also has been found to inhibit the $\mathrm{HBx}-\mathrm{DDB} 1$ protein interaction in HBV. Significant suppression of viral transcription and viral protein production in the HBV minicircle system and in human primary hepatocytes naturally infected with $\mathrm{HBV}$ was noted. ${ }^{83}$ In addition, there are reports of NTZ and TIZ having potential utility in the treatment of Ebola through broad amplification of the host innate immune response to viruses and subsequent suppression of Ebola virus replication as demonstrated in vitro using multiple cell lines and genome editing techniques. From an immune response perspective, NTZ enhances multiple pathways including retinoic-acidinducible protein I (RIG-I)-like-receptor, mitochondrial antiviral signaling protein, interferon regulatory factor 3 , and interferon activities and induces transcription of the antiviral phosphatase GADD34. RIG-I plays a particularly important role in the identification of cells infected by intracellular pathogens and helps maintain host-cell integrity. NTZ significantly inhibits Ebola replication in human cells through its effects on RIG-I and PKR. ${ }^{84}$

Inhibition of the protease complex NS2B-NS3 is the target for NTZ in Zika virus as determined by an in vitro screen to identify orthosteric inhibitors that directly target flavivirus NS2B-NS3 interactions. The complex plays an essential role during flaviviral polyprotein processing and thus represents an attractive drug target. ${ }^{85}$ Within Paramyxoviridae (PMV, a large family of enveloped viruses including important human pathogens such as measles, mumps, and respiratory syncytial virus (RSV)) NTZ inhibits viral replication by targeting thiol oxidoreductase ERp57 involved in the fusion protein folding process as demonstrated using multiple in vitro techniques on monkey kidney (AGMK) cells infected with Sendai virus $(\mathrm{SeV}){ }^{86}$

More recently, studies have been undertaken into the role of NTZ and TIZ in the treatment of the Middle East respiratory syndrome coronavirus (MERS-CoV). ${ }^{28,70} \mathrm{NTZ}$ inhibits the production of pro-inflammatory cytokines TNF- $\alpha$, IL-2, IL-4, IL-5, IL-6, IL-8, and IL-10 in peripheral blood mononuclear cells (PBMCs) and results in reduced viral protein accumulation in cells, possibly due to inhibition of viral $\mathrm{N}$ protein expression but further work is required to fully ascertain this. While not yet studied in humans (current studies have been completed in an in vivo mouse model and in mouse macrophages), this data suggests that NTZ could potentially improve outcomes in patients infected with MERS-CoV/ SARS-CoV-2 by suppressing overproduction of pro-inflammatory cytokines, including IL- $6 .{ }^{87}$ Further studies are required to fully elucidate the mechanism of action of NTZ/TIZ against coronaviruses, but the current knowledge clearly orients NTZ toward a potential role in the treatment of SARS-CoV-2. 
<smiles>CCOc1ccccc1C(=O)Nc1ncc([N+](=O)[O-])s1</smiles>

Nitazoxanide (4)

$\mathrm{IC}_{50} 3.3 \mu \mathrm{M}, \mathrm{SI}>50$<smiles>O=C(Nc1ncc(Cl)s1)c1ccccc1O</smiles>

RM4848 (8)

HBV Further development<smiles>O=C(Nc1ncc([N+](=O)[O-])s1)c1ccccc1O</smiles>

Tizoxanide (6)

$\mathrm{IC}_{50} 3.8 \mu \mathrm{M}, \mathrm{SI}>50$<smiles>N#Cc1cnc(NC(=O)c2ccccc2O)s1</smiles>

(9)

$\mathrm{IC}_{50} 4.1 \mu \mathrm{M}, \mathrm{SI}>50$<smiles>CC(=O)Oc1ccccc1C(=O)Nc1ncc(Br)s1</smiles>

RM4819 (12)

$I_{50} 5.9 \mu \mathrm{M}, \mathrm{SI}>25$<smiles>CC(=O)Oc1ccccc1C(=O)Nc1ncc(Cl)s1</smiles>

RM5038 (7)

IC $503.4 \mu \mathrm{M}, \mathrm{SI}=20$

$\mathrm{HCV}$ preclinical<smiles>CCOc1csc(NC(=O)c2ccccc2OC(C)=O)n1</smiles>

RM5021 (10)

$\mathrm{IC}_{50} 0.14 \mu \mathrm{M}, \mathrm{SI}>1000$

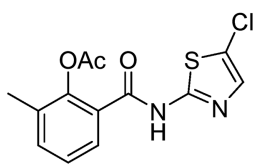

(13)

$\mathrm{IC}_{50} 12.9 \mu \mathrm{M}, \mathrm{SI}=6.2$<smiles>CC(C)C[C@H](N=[18O])C(=O)Oc1ccccc1C(=O)Nc1ncc([N+](=O)[O-])s1</smiles>

Figure 5. NTZ and various lead thiazolides: Antiviral activity of representatives vs influenza A virus.

\section{NTZ PHARMACOKINETICS IN HUMAN AND PREDICTED ACCUMULATION IN LUNG}

NTZ (500 mg, twice daily for 3 days) was approved for the treatment of diarrhea caused by Giardia lamblia or Cryptosporidium parvum in adult patients. In reported offlabel uses for other indications, that is, Clostridioides difficile infection $^{88}$ or cryptosporidiosis-associated diarrhea in HIVinfected patients, ${ }^{89}$ the dosage and regimen of NTZ was increased to up to $1000 \mathrm{mg}$ twice daily for 14 days at most. There were a number of phase 1 clinical trials reported in the literature with extensive pharmacokinetic data in human. For example, in the paper by Stockis et al. published in $1996,{ }^{90}$ the first exploratory trial of a $500 \mathrm{mg}$ single dose of NTZ in humans was described along with some basic pharmacokinetic findings of NTZ in humans, for example, the detectable species in plasma is its metabolite, TIZ. Thus, all reported PK parameters after single $500 \mathrm{mg}$ oral dosing of NTZ, such as $C_{\max }(1.9 \mathrm{mg} / \mathrm{L}), T_{\max }(2-6 \mathrm{~h})$, AUC $(3.9-11.3 \mathrm{mg} \cdot \mathrm{h} / \mathrm{L})$, and terminal $T_{1 / 2}(1.03-1.6 \mathrm{~h})$ are based on TIZ concentrations in plasma. Once formed, TIZ primarily undergoes glucuronidation within the liver to form tizoxanide glucuronide (6a), which is excreted in the urine and bile; TIZ itself is also found to be eliminated from the body via the urine, bile, and feces. ${ }^{30}$ In 2002, two back-to-back publications both authored by Stockis and co-workers reported the findings from a single ascending dose (SAD) trial $(1,2,3$, and $4 \mathrm{~g}$ of NTZ dosed orally) and a multiple ascending dose $(\mathrm{MAD})$ trial $(0.5$ and 1 g, bid, for 7 days oral dosing of NTZ). ${ }^{36,91}$ All dosages (up to 4 $\mathrm{g}$ in a single dose $)$ and one multiple dosing regimen $(0.5 \mathrm{~g}$, bid for 7 days) were well tolerated with only mild adverse events. There was increased frequency of GI side effects reported in the $1 \mathrm{~g}$ bid, 7 days dosing group, but no significant changes to other parameters, that is, ECGs, vital signs, and laboratory tests. From the SAD trial, it was reported that (1) plasma concentrations of both major metabolites (TIZ and TG) increased largely in a linear correlation with the dose between 1 and $4 \mathrm{~g}$ and (2) the food effect is significant, approximately doubling the bioavailability and the concentrations of both metabolites in all dosing groups. At the highest $(4 \mathrm{~g})$ dosing with food, the two metabolites, TIZ and TG, could reach $C_{\max }$ of $70 \mu \mathrm{g} / \mathrm{mL}$ (TIZ) and $59.6 \mu \mathrm{g} / \mathrm{mL}$ (TG) and AUC of 768 $\mu \mathrm{g} \cdot \mathrm{h} / \mathrm{mL}(\mathrm{T})$ and $832 \mu \mathrm{g} \cdot \mathrm{h} / \mathrm{mL}$ (TG), although it was also noted that at this dosing level the $T_{\max }$ was delayed and the apparent elimination rate was noticeably lower than in the lower dosage level, particularly for the glucuronide metabolite. From the MAD trial, it was observed that at $0.5 \mathrm{~g}$ bid dosing level, the measured pharmacokinetic parameters of both metabolites were similar to the single dosing at the same level; on the other hand, at $1 \mathrm{~g}$ bid dosing, the bioavailability of both metabolites was increased noticeably (50-70\%), compared with single dosing, which indicated significant accumulation at repeat dosing at this level. Also, the report data obtained from the MAD study gave further evidence of the steady state of the exposure level of both metabolites, 


\section{(Aryl SAR)}

- Methylation = decrease in activity for Influenza $A$, varied activity for Hepatitis B and C

- Chlorination $=$ moderate activity vs Hepatitis B and $\mathrm{C}$

- Para hydroxy isomer of $\mathrm{TIZ}\left(\mathrm{R}^{3}=\mathrm{OH}\right)$ very active vs Influenza A

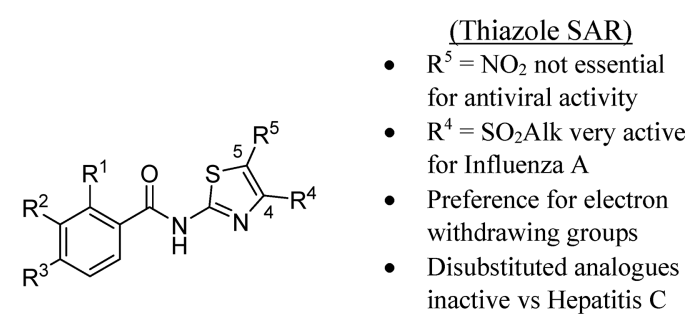

$\mathbf{R}^{1}=\mathrm{OAc}$ (NTZ), OH (TIZ)

\author{
(Thiazole SAR) \\ $\mathrm{R}^{5}=\mathrm{NO}_{2}$ not essential \\ $\mathrm{R}^{4}=\mathrm{SO}_{2}$ Alk very active \\ for Influenza $A$ \\ Preference for electro \\ Disubstituted analogues \\ inactive vs Hepatitis C
}

Figure 6. Antiviral SAR of NTZ/TIZ against influenza A, hepatitis B, and hepatitis C.

which can be used in human PK modeling to provide a further insight into PK profiles of NTZ at different dosing levels.

Using the pharmacokinetic data available in the public domain, it is feasible to simulate the exposure of TIZ at two dosing levels ( 0.5 and $1 \mathrm{~g}$, bid) for 7 days (Figure 4). However, there is very limited information available concerning the partition of the major metabolites between systemic circulation and specific organs, such as the lung. As a major site of infection for SARS-CoV-2, the concentrations of the major metabolites in the lung after oral dosing of NTZ should be taken into consideration as a major contributing factor in the prediction of the antiviral efficacy for the treatment or prevention of COVID-19. In a recently published report, ${ }^{92}$ a PBPK model was used to predict the partition ratios between plasma and lung for a number of repurposing candidate drugs for COVID-19. In combination of the simulation of repeat dosing NTZ and the predicted lung/plasma partition ratio, we can estimate the lung concentration of TIZ in comparison to the in vitro potency of TIZ against SARS-CoV-2 at the standard dosage $(0.5 \mathrm{~g}$, bid) and the elevated off-label dosage $(1.0 \mathrm{~g}$, bid) as repeated doses for 7 days (Figure 4). While at the highest off-label dose (1.0 g, bid) the simulated TIZ exposure in both plasma and the lung can be maintained above the in vitro $\mathrm{EC}_{90}$ for the majority of the dosing period. This preliminary $\mathrm{PK} / \mathrm{PD}$ analysis provides some evidence to support the repurposing of NTZ for the treatment of COVID-19. Ongoing animal PK studies at Liverpool are aiming to define the pulmonary concentrations of nitazoxanide after oral administration. Furthermore, based upon our dose predictions for nitazoxanide, ${ }^{85}$ a trial involving a $1500 \mathrm{mg}$ bid dose of nitazoxanide has received funding from Unitaid and approval from the independent scientific advisory board for evaluation within a phase I/IIa study in the COVID19 platform trial known as AGILE (www.agiletrial.net).

A number of registered clinical trials (Please refer to Table 3 for a list of NTZ and COVID-19 related trials. $)^{93}$ in several countries (e.g., the U.S., Brazil, Mexico, South Africa, India and Egypt etc.) related to NTZ will provide further evidence to support the nitazoxanide repurposing effort; however, further detailed investigation through $\mathrm{PK} / \mathrm{PD}$ modeling, including provision of in vitro activity of TIZ and its glucuronide against SARS-CoV-2 in the most physiological relevant conditions (selection of host cell line, assay media, and multiplicity of infection, etc., could significantly affect the outcome of in vitro antiviral activity for the same drug; this was observed and analyzed in some recent reports ${ }^{73}$ concerning the in vitro screening of SARS-CoV-2) and simulation of the concentrations of both metabolites in the lung at different dosages and regimen will provide critical information to guide better design of clinical trials and understanding of trial results.

\section{THIAZOLIDE ANALOGUES: BRIEF OVERVIEW OF LITERATURE EXAMPLES AND ANTIVIRAL SAR}

With NTZ/TIZ demonstrating clear potential in treatment of SARS-CoV-2, it is also important to consider the multiple thiazolide analogues that are present within the literature as they could facilitate improved SARS-CoV-2 therapy.

Figure 5 depicts antiviral potency of various thiazolides versus the H1N1 strain of influenza A virus. ${ }^{16}$ Both NTZ and RM4848 (8) are being evaluated versus HBV, the former is in clinical trials, and the latter is in preclinical development. In general, the $\mathrm{IC}_{50}$ values for the parent prodrug acetates, for example, NTZ (4), RM5038 (7), and RM5021 (10), are similar to their phenolic metabolites. This includes other prodrug variants such as the tert-butyl amino prodrug (14) listed in Figure 5. In terms of development status, RM5038 and RM5021 are currently being evaluated in animal preclinical studies.

There are no reported SAR studies on analogues of nitazoxanide where an attempt is made to tease out direct antiviral versus host mediated effects in in vitro assays by traditional medicinal chemistry, and so moving forward phenotypic screening will remain key to expanding SAR in this field. For potential future lead optimization chemistry versus coronaviruses, SAR trends across other viruses provide valuable informative data on starting points. With this in mind, we have examined available data as a guide for future thiazolide lead optimization campaigns. Currently, the SAR for NTZ/ TIZ's antiviral activity is relatively limited and is summarized in Figure 6 (with representatives included in Figure 5). Functionalization of both the thiazole and phenyl rings has been performed against hepatitis $B$, hepatitis $C$, and influenza A. ${ }^{16,27,29}$ One significant difference between NTZ's antiviral versus its antibacterial activity is the importance of the nitro group attached to the $\mathrm{C} 5$ position of the thiazole ring. Previous SAR studies into NTZ's anaerobic antibacterial activity have shown the nitro group to be essential for activity, with deletion or modification completely abolishing activity. ${ }^{94-96}$ One study demonstrated the importance of the nitro group being a result of its ability to be reduced into a hydroxylamine, forming a key intermediate in its mechanism of action against anaerobes. ${ }^{94}$ Moreover, previous work evaluating the SAR of NTZ against Mycobacterium tuberculosis has also shown that removal of the nitro group results in inactivity. ${ }^{24}$

Conversely, a number of thiazolide analogues (Figure 5) have shown the nitro group to not be essential for antiviral activity. In particular, direct replacement of the nitro group with other electron withdrawing substituents has provided analogues with good antiviral activity. That the nitro group is not essential for antiviral activity is significant since it rules out a redox based mechanism of action (bioactivation by reduction 
Scheme 1. Synthesis of a $4^{\prime}$-(Ethylsulfonyl)thiazole ${ }^{a}$

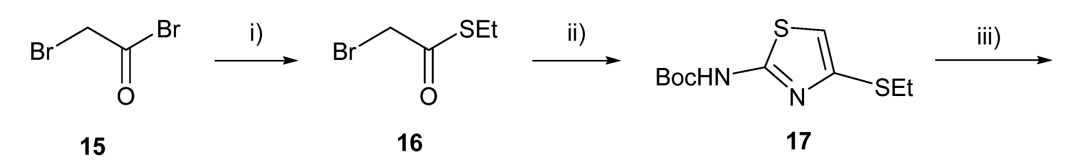

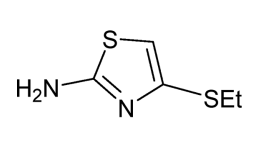

18

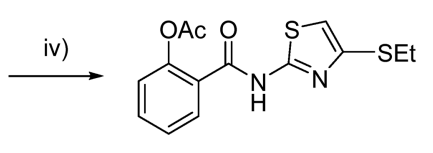

19

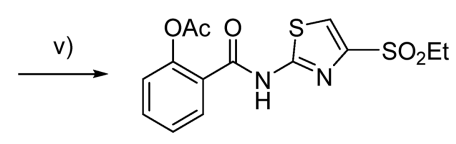

10

${ }^{a}$ Conditions and yields (i) NaSEt, $\mathrm{Et}_{2} \mathrm{O}, 86 \%$; (ii) $\mathrm{BocNHCSNH}_{2}$ 10, ${ }^{\mathrm{i}} \mathrm{PrOH}, 4 \AA \mathrm{A} \mathrm{MS}, 55 \%$; (iii) dil. TFA, $\mathrm{CH}_{2} \mathrm{Cl}_{2}$, then aq. $\mathrm{NaHCO}_{3}$, extract with $\mathrm{Et}_{2} \mathrm{O}, 96 \%$; (iv) $\mathrm{O}$-acetylsalicyloyl chloride, $\mathrm{CH}_{2} \mathrm{Cl}_{2}, \mathrm{NMM}, 81 \%$; (v) mCPBA (2.2 equiv), $\mathrm{CH}_{2} \mathrm{Cl}_{2}, 95 \%$.

and redox cycling) and increases the drug-like properties of the thiazolide analogue. While nitazoxanide has been shown to be a well-tolerated drug clinically, it is well evidenced that drugs containing nitro groups can induce severe toxicity with the nitro aromatic or heterocycle being classed as a metabolic alert. Thus, analogues removing this liability while maintaining potency will have a clear potential advantage. ${ }^{97}$

Overall, the antiviral SAR work carried out so far against hepatitis $B$, hepatitis $C$, and influenza $A$ has shown a clear preference for electron withdrawing groups attached to not only the $\mathrm{C} 5$ but also the $\mathrm{C} 4$ position of the thiazole ring. ${ }^{16,27,29}$ As shown in Figure 5, a significant improvement in influenza A activity can be achieved with the incorporation of alkylsulfone groups at the C4 position. ${ }^{16}$ Only two $4^{\prime}, 5^{\prime}$-disubstituted analogues have been reported so far $\left(4^{\prime}-\mathrm{Me} / 5^{\prime}-\mathrm{Br}\right.$ and $4^{\prime}-\mathrm{Ph} /$ $5^{\prime}-\mathrm{Br}$ ), however both proved to be inactive against hepatitis C. ${ }^{29}$

In addition to investigation of the thiazole ring, substitution on the phenyl ring also has been of interest in determining the overall antiviral SAR of NTZ/TIZ analogues. Methylation at the different positions around the phenyl ring typically causes a decrease in antiviral activity against influenza A. ${ }^{16}$ However, for hepatitis $\mathrm{B}$ and $\mathrm{C}$, methylation around the phenyl ring has a much more varied effect on antiviral activity. Halogenation of the phenyl ring has also been explored for hepatitis $\mathrm{B}$ and $\mathrm{C}$. Chlorination of TIZ and the $5^{\prime}-\mathrm{Br}$ analogue results in moderate activity. ${ }^{27,29}$ Interestingly for influenza A, the para hydroxy isomer of TIZ shows a 10 -fold increase in activity. ${ }^{16}$ The free phenol, or its precursor the acetate (or other prodrug ester), is essential for activity. Even methylation to the $O$ methyl ether virtually abolishes all activity. ${ }^{98}$ It does appear that a free $\mathrm{NH}$ and a free $\mathrm{OH}$ are both required for active thiazolides.

\section{SYNTHETIC CHEMISTRY OF NITAZOXANIDE, PRODRUGS, AND IMPROVED THIAZOLIDES}

One of the attractive features of NTZ and other thiazolides is that a general synthesis is available for a wide range of analogues starting from commercially available $\mathrm{O}$-acetylsalicyloyl chloride by reaction with an appropriate 2-amino-5substituted thiazole. In the case of NTZ 4 itself, the use of $\mathrm{Et}_{3} \mathrm{~N}$ as base and THF as solvent is necessary; 2-amino-5nitrothiazole is poorly soluble and a weak nucleophile. In cases where the aminothiazole is a better nucleophile, a two-phase procedure, viz. $\mathrm{CH}_{2} \mathrm{Cl}_{2}$ or EtOAc/aq. $\mathrm{NaHCO}_{3}$, may be a good and simple alternative. This is effective for the $\mathrm{HCl}$ salt of 2-amino-5-chlorothiazole, leading to the 5-Cl analogue 7 in high yield. The Liverpool group studied many coupling methods, for example, HATU and other uronium reagents, which we have summarized previously. ${ }^{27,29}$

A related series of molecules are $4^{\prime}$-substituted thiazolides. In general, 2-amino-4-X-thiazoles, with the exception of $\mathrm{X}=\mathrm{Ph}$ or $\mathrm{Br} / \mathrm{Cl}$, are not readily available, and multistep syntheses may be required to access the corresponding thiazolides. An important example is the $4^{\prime}$-ethylsulfonyl thiazolide 10, which showed outstanding activity against an $\mathrm{H} 1 \mathrm{~N} 1$ strain of influenza $\mathrm{A}$ virus, $\mathrm{IC}_{50}=0.14 \mu \mathrm{M} .{ }^{16}$ This analogue was synthesized by a five-step route from bromoacetyl bromide $\mathbf{1 5}$ (Scheme 1). ${ }^{99}$

As noted, an important point when considering the potential of NTZ as an antiviral is that it behaves in vivo as a prodrug for the free phenol, TIZ (6); the acetate ester is readily cleaved by esterases in the blood. ${ }^{36}$ A number of alternative acyl groups have been studied, but none showed a significant advantage over $4 .^{27}$ If TIZ 6 itself is needed, the acetate in 4 may be cleaved using mild acid (aq. $\mathrm{HCl}, 60{ }^{\circ} \mathrm{C}$ ) or base (aq. $\mathrm{NH}_{3}$, $\mathrm{THF}, 20{ }^{\circ} \mathrm{C}$ then $\mathrm{HCl}$ to $\left.\mathrm{pH} 1\right)$. In regards to biological screening, for any particular thiazolide, the acetate and free phenol are essentially equiactive. The free phenol is invariably the active circulating metabolite in vivo.

The human metabolism of thiazolides has been studied in detail only for NTZ 4 and RM5038 7. Once the ester has been cleaved, the majority of the circulating dose is cleared as the $O$ glucuronide; $O$-sulfation is only a minor pathway. Compounds $\mathbf{4}$ and $\mathbf{7}$ are not significantly bioactivated by a panel of CYPs; it appears that the electron-withdrawing substituent at $\mathrm{C}(5)$ prevents oxidative metabolism. ${ }^{30}$ It has yet to be determined whether a $4^{\prime}$-electron withdrawing substituent as in $\mathbf{1 0}$ is equally effective. By contrast, 4,5-unsubstituted thiazoles are typically CYP-oxidized leading to toxic thiourea metabolites. ${ }^{100,101}$

The solubilities of the thiazolides, especially as the free phenols, are not optimal for good systemic absorption for the treatment of respiratory viruses. One widely used method of improving the oral absorption of a number of drugs is the use of a pro-drug ester. A relevant example is the valine derivative valcyclovir 20, ${ }^{102,103}$ which increases the oral absorption of its parent, the antiviral agent acyclovir, 21 from 20\% to 54\%. A similar amino-acid derivative of TIZ (14) (Figure 5), expected to show superior solubility and bioavailability to the acetate esters NTZ 4 and 7, has been prepared and is currently undergoing investigation. ${ }^{19}$

While it appears that thiazolides discussed in this review (e.g. NTZ and RM5038/4848) can both affect terminal glycosylation and transport of viral hemagglutinin to the cell plasma-membrane, additional studies on analogues have not been performed to correlate this activity with measured 
<smiles></smiles><smiles>Nc1nc2c(ncn2COCCO)c(=O)[nH]1</smiles>

21

antiviral effect in culture, and this will be important in future target validation studies. Another aspect of research that should follow would be to examine the propensity of an analogue series to affect key host factors. Very recent studies have demonstrated that NTZ inhibits host ERp57 activity, causing newly synthesized F-protein misfolding and Faggregate formation and halting F-trafficking to the host plasma membrane. Additional studies in multiple viruses implicate additional host targets, but to date there are no SARs to relate drug structure to function in these host mediated effects; again this should be the subject of additional research.

\section{CONCLUSIONS}

NTZ has a broad spectrum of anti-infective activity mediated through modulation of host innate immune responses as well as direct activity against multiple viral targets. NTZ has been shown to improve clinical outcome when used against multiple respiratory viruses and has been shown to have in vitro activity against the coronaviruses, including SARS-CoV-2. This, combined with its ease of synthesis, established human pharmacokinetics, favorable preliminary $\mathrm{PK} / \mathrm{PD}$ simulations of plasma and lung accumulation, and extensive pharmacological safety testing in both animals and humans highlights the therapeutic potential of NTZ.

While there are still questions to be answered with respect to the mode of action of NTZ within SARS-CoV-2, the utility of thiazolide analogues and pro-drugs, and more detailed PK/PD modeling in order to inform further clinical trials, NTZ and its second generation thiazolides without doubt have the potential to be appropriate choices for repurposing versus SARS-CoV-2 either as monotherapy or as part of combinations. With combination therapy in mind Bobrowski and co-workers have completed a very recent in silico guided in vitro analysis of possible drug combinations for SARS CoV-2. ${ }^{104}$ From the 16 synergistic cases, combinations of nitazoxanide with three other compounds (remdesivir, amodiaquine, and umifenovir) were the most notable, all exhibiting significant synergy against SARS-CoV-2. Based on this observation, it would seem logical to consider clinical trials of remdesivir with nitazoxanide given the FDA approval of the former for use in COVID-19 infection. Using our online drug-drug interactions tool, we would not expect any significant drug-drug interactions between remdesivir and nitazoxanide. ${ }^{105}$ Clearly, to realize the full potential of NTZ against COVID-19, further assessments of safety and efficacy at current and elevated doses should be investigated in ongoing and future clinical trials. ${ }^{106,107}$

\section{ASSOCIATED CONTENT}

\section{SI Supporting Information}

The Supporting Information is available free of charge at https://pubs.acs.org/doi/10.1021/acsinfecdis.0c00478.

Methods of SARS-CoV-2 antiviral determination, dose response curves for nitazoxanise and tizoxanide against
SARS-CoV-2 in vitro, summary of clinical trials conducted with NTZ (PDF)

\section{AUTHOR INFORMATION}

Corresponding Authors

Paul M. O'Neill - Department of Chemistry, University of Liverpool, Liverpool L69 7ZD, U.K.; 이이이.org/00000003-4338-0317; Phone: 0151794 3553;

Email: pmoneill@liverpool.ac.uk

Andrew V. Stachulski - Department of Chemistry, University of Liverpool, Liverpool L69 7ZD, U.K.; Phone: 0151794 3482; Email: stachuls@liverpool.ac.uk

\section{Authors}

Joshua Taujanskas - Department of Chemistry, University of Liverpool, Liverpool L69 7ZD, U.K.

Sophie L. Pate - Department of Chemistry, University of Liverpool, Liverpool L69 7ZD, U.K.

Rajith K. R. Rajoli - Department of Molecular and Clinical Pharmacology, Materials Innovation Factory, University of Liverpool, Liverpool L7 3NY, U.K.

Ghaith Aljayyoussi - Centre for Drugs and Diagnostics, Department of Tropical Disease Biology, Liverpool School of Tropical Medicine, Liverpool L3 5QA, U.K.

Shaun H. Pennington - Centre for Drugs and Diagnostics, Department of Tropical Disease Biology, Liverpool School of Tropical Medicine, Liverpool L3 5QA, U.K.

Stephen A. Ward - Centre for Drugs and Diagnostics, Department of Tropical Disease Biology, Liverpool School of Tropical Medicine, Liverpool L3 5QA, U.K.

Weiqian David Hong - Department of Chemistry, University

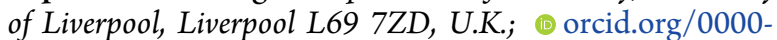
0002-0030-3007

Giancarlo A. Biagini - Centre for Drugs and Diagnostics, Department of Tropical Disease Biology, Liverpool School of Tropical Medicine, Liverpool L3 5QA, U.K.

Andrew Owen - Department of Molecular and Clinical Pharmacology, Materials Innovation Factory, University of Liverpool, Liverpool L7 3NY, U.K.

Gemma L. Nixon - Department of Chemistry, University of Liverpool, Liverpool L69 7ZD, U.K.; ○ orcid.org/00000002-9730-0960

Suet C. Leung - Department of Chemistry, University of Liverpool, Liverpool L69 7ZD, U.K.

Complete contact information is available at:

https://pubs.acs.org/10.1021/acsinfecdis.0c00478

\section{Funding}

A.V.S., P.O.N., G.N., S.P., and J.T. acknowledge research funding from Romark Global Pharma LCC. G.A.B. acknowledges support from the Medical Research Council (MR/ S00467X/1). A.O. acknowledges research funding from Unitaid (LONGEVITY) and EPSRC (EP/R024804/1).

Notes

The authors declare no competing financial interest.

\section{REFERENCES}

(1) Zhu, N., Zhang, D., Wang, W., Li, X., Yang, B., Song, J., Zhao, X., Huang, B., Shi, W., Lu, R., Niu, P., Zhan, F., Ma, X., Wang, D., Xu, W., Wu, G., Gao, G. F., and Tan, W. (2020) A Novel Coronavirus from Patients with Pneumonia in China, 2019. N. Engl. J. Med. 382 (8), 727-733. 
(2) Huang, C., Wang, Y., Li, X., Ren, L., Zhao, J., Hu, Y., Zhang, L., Fan, G., Xu, J., Gu, X., Cheng, Z., Yu, T., Xia, J., Wei, Y., Wu, W., Xie, X., Yin, W., Li, H., Liu, M., Xiao, Y., Gao, H., Guo, L., Xie, J., Wang, G., Jiang, R., Gao, Z., Jin, Q., Wang, J., and Cao, B. (2020) Clinical features of patients infected with 2019 novel coronavirus in Wuhan, China. Lancet 395 (10223), 497-506.

(3) Zhou, P., Yang, X.-L., Wang, X.-G., Hu, B., Zhang, L., Zhang, W., Si, H.-R., Zhu, Y., Li, B., Huang, C.-L., Chen, H.-D., Chen, J., Luo, Y., Guo, H., Jiang, R.-D., Liu, M.-Q., Chen, Y., Shen, X.-R., Wang, X., Zheng, X.-S., Zhao, K., Chen, Q.-J., Deng, F., Liu, L.-L., Yan, B., Zhan, F.-X., Wang, Y.-Y., Xiao, G.-F., and Shi, Z.-L. (2020) A pneumonia outbreak associated with a new coronavirus of probable bat origin. Nature 579 (7798), 270-273.

(4) WHO Coronavirus Disease (COVID-19) Dashboard. https:// covid19.who.int/ (accessed 30/10/2020).

(5) Liu, C., Zhou, Q., Li, Y., Garner, L. V., Watkins, S. P., Carter, L. J., Smoot, J., Gregg, A. C., Daniels, A. D., Jervey, S., and Albaiu, D. (2020) Research and Development on Therapeutic Agents and Vaccines for COVID-19 and Related Human Coronavirus Diseases. ACS Cent. Sci. 6 (3), 315-331.

(6) Draft landscape of COVID-19 candidate vaccines. https://www. who.int/publications/m/item/draft-landscape-of-covid-19-candidatevaccines (accessed 30/10/2020).

(7) Ramasamy, M. N., Minassian, A. M., Ewer, K. J., Flaxman, A. L., Folegatti, P. M., Owens, D. R., Voysey, M., Aley, P. K., Angus, B., Babbage, G., Belij-Rammerstorfer, S., et al. (2020) Safety and immunogenicity of ChAdOxl $\mathrm{nCoV}-19$ vaccine administered in a prime-boost regimen in young and old adults (COV002): a singleblind, randomised, controlled, phase 2/3 trial. Lancet 396, 1979.

(8) Wang, M., Cao, R., Zhang, L., Yang, X., Liu, J., Xu, M., Shi, Z., $\mathrm{Hu}, \mathrm{Z}$., Zhong, W., and Xiao, G. (2020) Remdesivir and chloroquine effectively inhibit the recently emerged novel coronavirus (2019$\mathrm{nCoV}$ ) in vitro. Cell Res. 30 (3), 269-271.

(9) Sheahan, T. P., Sims, A. C., Graham, R. L., Menachery, V. D., Gralinski, L. E., Case, J. B., Leist, S. R., Pyrc, K., Feng, J. Y., Trantcheva, I., Bannister, R., Park, Y., Babusis, D., Clarke, M. O., Mackman, R. L., Spahn, J. E., Palmiotti, C. A., Siegel, D., Ray, A. S., Cihlar, T., Jordan, R., Denison, M. R., and Baric, R. S. (2017) Broadspectrum antiviral GS-5734 inhibits both epidemic and zoonotic coronaviruses. Sci. Transl. Med. 9 (396), No. eaal3653.

(10) Warren, T. K., Jordan, R., Lo, M. K., Ray, A. S., Mackman, R. L., Soloveva, V., Siegel, D., Perron, M., Bannister, R., Hui, H. C., Larson, N., Strickley, R., Wells, J., Stuthman, K. S., Van Tongeren, S. A., Garza, N. L., Donnelly, G., Shurtleff, A. C., Retterer, C. J., Gharaibeh, D., Zamani, R., Kenny, T., Eaton, B. P., Grimes, E., Welch, L. S., Gomba, L., Wilhelmsen, C. L., Nichols, D. K., Nuss, J. E., Nagle, E. R., Kugelman, J. R., Palacios, G., Doerffler, E., Neville, S., Carra, E., Clarke, M. O., Zhang, L., Lew, W., Ross, B., Wang, Q., Chun, K., Wolfe, L., Babusis, D., Park, Y., Stray, K. M., Trancheva, I., Feng, J. Y., Barauskas, O., Xu, Y., Wong, P., Braun, M. R., Flint, M., McMullan, L. K., Chen, S.-S., Fearns, R., Swaminathan, S., Mayers, D. L., Spiropoulou, C. F., Lee, W. A., Nichol, S. T., Cihlar, T., and Bavari, S. (2016) Therapeutic efficacy of the small molecule GS-5734 against Ebola virus in rhesus monkeys. Nature 531 (7594), 381-385.

(11) Savarino, A., Di Trani, L., Donatelli, I., Cauda, R., and Cassone, A. (2006) New insights into the antiviral effects of chloroquine. Lancet Infect. Dis. 6 (2), 67-69.

(12) Vincent, M. J., Bergeron, E., Benjannet, S., Erickson, B. R., Rollin, P. E., Ksiazek, T. G., Seidah, N. G., and Nichol, S. T. (2005) Chloroquine is a potent inhibitor of SARS coronavirus infection and spread. Virol. J. 2 (1), 69.

(13) Taccone, F. S., Gorham, J., and Vincent, J.-L. (2020) Hydroxychloroquine in the management of critically ill patients with COVID-19: the need for an evidence base. Lancet Respir. Med. 8, 539.

(14) Rossignol, J.-F. A., Ayoub, A., and Ayers, M. S. (2001) Treatment of Diarrhea Caused by Cryptosporidium parvum: A Prospective Randomized, Double-Blind, Placebo-Controlled Study of Nitazoxanide. J. Infect. Dis. 184 (1), 103-106.
(15) Rossignol, J.-F. (2014) Nitazoxanide: A first-in-class broadspectrum antiviral agent. Antiviral Res. 110, 94-103.

(16) Stachulski, A. V., Santoro, M. G., Piacentini, S., Belardo, G., Frazia, S. L., Pidathala, C., Row, E. C., Berry, N. G., Iqbal, M., Allman, S. A., Semple, J. E., Eklov, B. M., O’Neill, P. M., and Rossignol, J.-F. (2018) Second-generation nitazoxanide derivatives: thiazolides are effective inhibitors of the influenza A virus. Future Med. Chem. 10 (8), $851-862$.

(17) Jeon, S., Ko, M., Lee, J., Choi, I., Byun, S. Y., Park, S., Shum, D., and Kim, S. (2020) Identification of Antiviral Drug Candidates against SARS-CoV-2 from FDA-Approved Drugs. Antimicrob. Agents Chemother. 64 (7), No. e00819-20.

(18) Xu, J., Shi, P.-Y., Li, H., and Zhou, J. (2020) Broad Spectrum Antiviral Agent Niclosamide and Its Therapeutic Potential. ACS Infect. Dis. 6 (5), 909-915.

(19) Stachulski, A. V., Swift, K., Cooper, M., Reynolds, S., Norton, D., Slonecker, S. D., and Rossignol, J.-F. (2017) Synthesis and preclinical studies of new amino-acid ester thiazolide prodrugs. Eur. J. Med. Chem. 126, 154-159.

(20) DrugBank https://www.drugbank.ca/drugs/DB00507.

(21) Valladares-Méndez, A., García-Flores, M., Navarrete-Vázquez, G., Orozco-Castellanos, L. M., Hernandez-Nuñez, E., and RiveraLeyva, J. C. (2017) Physicochemical characterization of two new Nitazoxanide analogs with antiparasitic activity. Med. Chem. Res. 26 (1), 9-18.

(22) Singh, N., and Narayan, S. (2011) Nitazoxanide: A Broad Spectrum Antimicrobial. Medical Journal Armed Forces India 67 (1), 67-68.

(23) Dubreuil, L., Houcke, I., Mouton, Y., and Rossignol, J. F. (1996) In vitro evaluation of activities of nitazoxanide and tizoxanide against anaerobes and aerobic organisms. Antimicrob. Agents Chemother. 40 (10), 2266-2270.

(24) Odingo, J., Bailey, M. A., Files, M., Early, J. V., Alling, T., Dennison, D., Bowman, J., Dalai, S., Kumar, N., Cramer, J., Masquelin, T., Hipskind, P. A., and Parish, T. (2017) In Vitro Evaluation of Novel Nitazoxanide Derivatives against Mycobacterium tuberculosis. ACS Omega 2 (9), 5873-5890.

(25) Hoffman, P. S., Sisson, G., Croxen, M. A., Welch, K., Harman, W. D., Cremades, N., and Morash, M. G. (2007) Antiparasitic drug nitazoxanide inhibits the pyruvate oxidoreductases of Helicobacter pylori, selected anaerobic bacteria and parasites, and Campylobacter jejuni. Antimicrob. Agents Chemother. 51 (3), 868-876.

(26) de Carvalho, L. P. S., Darby, C. M., Rhee, K. Y., and Nathan, C. (2011) Nitazoxanide Disrupts Membrane Potential and Intrabacterial $\mathrm{pH}$ Homeostasis of Mycobacterium tuberculosis. ACS Med. Chem. Lett. 2 (11), 849-854.

(27) Stachulski, A. V., Pidathala, C., Row, E. C., Sharma, R., Berry, N. G., Iqbal, M., Bentley, J., Allman, S. A., Edwards, G., Helm, A., Hellier, J., Korba, B. E., Semple, J. E., and Rossignol, J.-F. (2011) Thiazolides as novel antiviral agents. 1. Inhibition of hepatitis B virus replication. J. Med. Chem. 54 (12), 4119-4132.

(28) Rossignol, J.-F. (2016) Nitazoxanide, a new drug candidate for the treatment of Middle East respiratory syndrome coronavirus. Journal of Infection and Public Health 9 (3), 227-230.

(29) Stachulski, A. V., Pidathala, C., Row, E. C., Sharma, R., Berry, N. G., Lawrenson, A. S., Moores, S. L., Iqbal, M., Bentley, J., Allman, S. A., Edwards, G., Helm, A., Hellier, J., Korba, B. E., Semple, J. E., and Rossignol, J.-F. (2011) Thiazolides as Novel Antiviral Agents. 2. Inhibition of Hepatitis C Virus Replication. J. Med. Chem. 54 (24), $8670-8680$.

(30) Broekhuysen, J., Stockis, A., Lins, R. L., De Graeve, J., and Rossignol, J. F. (2000) Nitazoxanide: pharmacokinetics and metabolism in man. Int. J. Clin. Pharmacol. Ther. 38 (8), 387-394.

(31) Vets, E., Rossignol, J.-F., and Jackson, A. S. (2009) Effects of nitazoxanide on pharmacokinetics and pharmacodynamics of a single dose of warfarin. Am. J. Health-Syst. Pharm. 66 (9), 838-842.

(32) Zhao, Z., Xue, F., Zhang, L., Zhang, K., Fei, C., Zheng, W., Wang, X., Wang, M., Zhao, Z., and Meng, X. (2010) The pharmacokinetics of nitazoxanide active metabolite (tizoxanide) in 
goats and its protein binding ability in vitro. J. Vet. Pharmacol. Ther. 33 (2), $147-153$.

(33) Rossignol, J. F., Ayoub, A., and Ayers, M. S. (2001) Treatment of Diarrhea Caused by Giardia intestinalis and Entamoeba histolytica or E. dispar: A Randomized, Double-Blind, Placebo-Controlled Study of Nitazoxanide. J. Infect. Dis. 184 (3), 381-384.

(34) Keeffe, E. B., and Rossignol, J.-F. (2009) Treatment of chronic viral hepatitis with nitazoxanide and second generation thiazolides. World J. Gastroenterol. 15 (15), 1805-1808.

(35) Ramos-Soriano, A. G., and Black, J. (2015) Nitazoxanide Use as Part of an Empiric Multi-Drug Regimen in Treating Children with Suspected Helicobacter pylori Infection. Case Rep. Gastroenterol. 9 (1), 36-42.

(36) Stockis, A., Allemon, A. M., De Bruyn, S., and Gengler, C. (2002) Nitazoxanide pharmacokinetics and tolerability in man using single ascending oral doses. Int. J. Clin. Pharmacol. Ther. 40 (5), 21320.

(37) Rossignol, J.-F. (2009) Thiazolides: a new class of antiviral drugs. Expert Opin. Drug Metab. Toxicol. 5 (6), 667-674.

(38) Santoro, M. G., Ciucci, A., Gianferretti, P., Belardo, G., La Frazia, S., Carta, S., and Rossignol, J.-F. (2007) Thiazolides: A New Class of Broad-Spectrum Antiviral Drugs Targeting Virus Maturation. Antiviral Res. 74 (3), A31.

(39) Gekonge, B., Bardin, M. C., and Montaner, L. J. (2015) Short communication: Nitazoxanide inhibits HIV viral replication in monocyte-derived macrophages. AIDS Res. Hum. Retroviruses 31 (2), 237-241.

(40) Trabattoni, D., Gnudi, F., Ibba, S. V., Saulle, I., Agostini, S., Masetti, M., Biasin, M., Rossignol, J.-F., and Clerici, M. (2016) Thiazolides Elicit Anti-Viral Innate Immunity and Reduce HIV Replication. Sci. Rep. 6 (1), 27148.

(41) Shi, Z., Wei, J., Deng, X., Li, S., Qiu, Y., Shao, D., Li, B., Zhang, K., Xue, F., Wang, X., and Ma, Z. (2014) Nitazoxanide inhibits the replication of Japanese encephalitis virus in cultured cells and in a mouse model. Virol. J. 11, 10.

(42) Wang, Y.-M., Lu, J.-W., Lin, C.-C., Chin, Y.-F., Wu, T.-Y., Lin, L.-I., Lai, Z.-Z., Kuo, S.-C., and Ho, Y.-J. (2016) Antiviral activities of niclosamide and nitazoxanide against chikungunya virus entry and transmission. Antiviral Res. 135, 81-90.

(43) Perelygina, L., Hautala, T., Seppänen, M., Adebayo, A., Sullivan, K. E., and Icenogle, J. (2017) Inhibition of rubella virus replication by the broad-spectrum drug nitazoxanide in cell culture and in a patient with a primary immune deficiency. Antiviral Res. 147, 58-66.

(44) Rossignol, J.-F., Abu-Zekry, M., Hussein, A., and Santoro, M. G. (2006) Effect of nitazoxanide for treatment of severe rotavirus diarrhoea: randomised double-blind placebo-controlled trial. Lancet 368 (9530), 124-129.

(45) Rossignol, J.-F., and El-Gohary, Y. M. (2006) Nitazoxanide in the treatment of viral gastroenteritis: a randomized double-blind placebo-controlled clinical trial. Aliment. Pharmacol. Ther. 24 (10), $1423-1430$

(46) La Frazia, S., Ciucci, A., Arnoldi, F., Coira, M., Gianferretti, P., Angelini, M., Belardo, G., Burrone, O. R., Rossignol, J.-F., and Santoro, M. G. (2013) Thiazolides, a New Class of Antiviral Agents Effective against Rotavirus Infection, Target Viral Morphogenesis, Inhibiting Viroplasm Formation. J. Virol. 87 (20), 11096-11106.

(47) Dang, W., Xu, L., Ma, B., Chen, S., Yin, Y., Chang, K.-O., Peppelenbosch, M. P., and Pan, Q. (2018) Nitazoxanide Inhibits Human Norovirus Replication and Synergizes with Ribavirin by Activation of Cellular Antiviral Response. Antimicrob. Agents Chemother. 62 (11), No. e00707-18.

(48) Korba, B. E., Montero, A. B., Farrar, K., Gaye, K., Mukerjee, S., Ayers, M. S., and Rossignol, J.-F. (2008) Nitazoxanide, tizoxanide and other thiazolides are potent inhibitors of hepatitis $\mathrm{B}$ virus and hepatitis C virus replication. Antiviral Res. 77 (1), 56-63.

(49) Khan, H., Paeshuyse, J., Murad, S., and Neyts, J. (2016) Assessment of the activity of directly acting antivirals and other products against different genotypes of hepatitis $\mathrm{C}$ virus prevalent in resource-poor countries. Antiviral Res. 125, 43-45.
(50) Yon, C., Viswanathan, P., Rossignol, J.-F., and Korba, B. (2011) Mutations in HCV non-structural genes do not contribute to resistance to nitazoxanide in replicon-containing cells. Antiviral Res. 91 (3), 233-240.

(51) Korba, B. E., Elazar, M., Lui, P., Rossignol, J.-F., and Glenn, J. S. (2008) Potential for Hepatitis C Virus Resistance to Nitazoxanide or Tizoxanide. Antimicrob. Agents Chemother. 52 (11), 4069-4071.

(52) Kolozsi, W., El-Gohary, Y., Keeffe, E., and Rossignol, J.-F. (2008) Treatment of Chronic Hepatitis B (CHB) with Nitazoxanide (Ntz) Alone or Ntz Plus Adefovir (ADV) for Two Years with Loss of Hepatitis B E Antigen (HBeAg) and Hepatitis B Surface Antigen (HbsAg): Report of Two Cases: 390. Am. J. Gastroenterol. 103, S150S151.

(53) Rossignol, J.-F., and Keeffe, E. B. (2008) Thiazolides: a new class of drugs for the treatment of chronic hepatitis B and C. Future Microbiol. 3 (5), 539-545.

(54) Rossignol, J.-F., and Bréchot, C. (2019) A Pilot Clinical Trial of Nitazoxanide in the Treatment of Chronic Hepatitis B. Hepatol. Commun. 3 (6), 744-747.

(55) Rossignol, J. F., Kabil, S. M., El-Gohary, Y., Elfert, A., and Keeffe, E. B. (2008) Clinical trial: randomized, double-blind, placebocontrolled study of nitazoxanide monotherapy for the treatment of patients with chronic hepatitis C genotype 4. Aliment. Pharmacol. Ther. 28 (5), 574-580.

(56) Rossignol, J. F., Elfert, A., El-Gohary, Y., and Keeffe, E. B. (2009) Improved Virologic Response in Chronic Hepatitis C Genotype 4 Treated With Nitazoxanide, Peginterferon, and Ribavirin. Gastroenterology 136 (3), 856-862.

(57) Rossignol, J.-F., Elfert, A., and Keeffe, E. (2010) Treatment of Chronic Hepatitis C Using a 4-week Lead-in With Nitazoxanide Before Peginterferon Plus Nitazoxanide. J. Clin. Gastroenterol. 44 (7), 504-509.

(58) Shiffman, M. L., Ahmed, A., Jacobson, I. M., Pruitt, R. E., and Keeffe, E. B. (2010) 1188 Phase 2 Randomized, Double-Blind, Placebo-Controlled Study of Nitazoxanide with Peginterferon alfa-2a and Ribavirin in Nonresponders (NR) with Chronic Hepatitis C Genotype 1: Final Report. J. Hepatol. 52, S461.

(59) Bacon, B. R., Shiffman, M. L., Lim, J. K., Berman, A., Rustgi, V. K., and Keeffe, E. B. (2010) A Phase II, Randomized, Double-Blind, Placebo-Controlled Study of Nitazoxanide Plus Peginterferon and Ribavirin in Naive Patients With Chronic Hepatitis C Genotype 1 Infection: Final Report. Gastroenterology 139 (1), No. e18.

(60) Shehab, H. M., Elbaz, T. M., and Deraz, D. M. (2014) Nitazoxanide plus pegylated interferon and ribavirin in the treatment of genotype 4 chronic hepatitis $\mathrm{C}$, a randomized controlled trial. Liver Int. 34 (2), 259-265.

(61) Rossignol, J. F., La Frazia, S., Chiappa, L., Ciucci, A., and Santoro, M. G. (2009) Thiazolides, a New Class of Anti-influenza Molecules Targeting Viral Hemagglutinin at the Post-translational Level. J. Biol. Chem. 284 (43), 29798-29808.

(62) Sleeman, K., Mishin, V. P., Guo, Z., Garten, R. J., Balish, A., Fry, A. M., Villanueva, J., Stevens, J., and Gubareva, L. V. (2014) Antiviral Susceptibility of Variant Influenza A(H3N2)v Viruses Isolated in the United States from 2011 to 2013. Antimicrob. Agents Chemother. 58 (4), 2045-2051.

(63) Tilmanis, D., van Baalen, C., Oh, D. Y., Rossignol, J.-F., and Hurt, A. C. (2017) The susceptibility of circulating human influenza viruses to tizoxanide, the active metabolite of nitazoxanide. Antiviral Res. 147, 142-148.

(64) Ashton, L. V., Callan, R. L., Rao, S., and Landolt, G. A. (2010) In vitro susceptibility of canine influenza A ( $\mathrm{H} 3 \mathrm{~N} 8$ ) virus to nitazoxanide and tizoxanide. Vet. Med. Int. 2010, 891010.

(65) Belardo, G., Cenciarelli, O., La Frazia, S., Rossignol, J. F., and Santoro, M. G. (2015) Synergistic Effect of Nitazoxanide with Neuraminidase Inhibitors against Influenza A Viruses In Vitro. Antimicrob. Agents Chemother. 59 (2), 1061-1069.

(66) An, L., Liu, R., Tang, W., Wu, J.-G., and Chen, X. (2014) Screening and identification of inhibitors against influenza $\mathrm{A}$ virus from a US drug collection of 1280 drugs. Antiviral Res. 109, 54-63. 
(67) Kim, Y., and Chang, K.-O. (2018) Protein disulfide isomerases as potential therapeutic targets for influenza A and B viruses. Virus Res. 247, 26-33.

(68) Haffizulla, J., Hartman, A., Hoppers, M., Resnick, H., Samudrala, S., Ginocchio, C., Bardin, M., Rossignol, J.-F., and US Nitazoxanide Influenza Clinical Study Group (2014) Effect of nitazoxanide in adults and adolescents with acute uncomplicated influenza: a double-blind, randomised, placebo-controlled, phase $2 \mathrm{~b} / 3$ trial. Lancet Infect. Dis. 14 (7), 609-618.

(69) Gamiño-Arroyo, A. E., Guerrero, M. L., McCarthy, S., RamírezVenegas, A., Llamosas-Gallardo, B., Galindo-Fraga, A., MorenoEspinosa, S., Roldán-Aragón, Y., Araujo-Meléndez, J., Hunsberger, S., Ibarra-González, V., Martínez-López, J., García-Andrade, L. A., Kapushoc, H., Holley, H. P., Smolskis, M. C., Ruiz-Palacios, G. M., Beigel, J. H., and Mexico Emerging Infectious Diseases Clinical Research Network (LaRed) (2019) Efficacy and Safety of Nitazoxanide in Addition to Standard of Care for the Treatment of Severe Acute Respiratory Illness. Clin. Infect. Dis. 69, 1903.

(70) Cao, J., Forrest, J. C., and Zhang, X. (2015) A screen of the NIH Clinical Collection small molecule library identifies potential anti-coronavirus drugs. Antiviral Res. 114, 1-10.

(71) https://opendata.ncats.nih.gov/covid19/databrowser.

(72) Nitazoxanide Dosage. https://www.drugs.com/dosage/ nitazoxanide.html (accessed 29/10/2020).

(73) Arshad, U., Pertinez, H., Box, H., Tatham, L., Rajoli, R. K., Curley, P., Neary, M., Sharp, J., Liptrott, N. J., Valentijn, A., David, C., Rannard, S. P., O’Neill, P., Aljayyoussi, G., Pennington, S., Ward, S. A., Back, D. J., Khoo, S. H., Bray, P. G., Biagini, G., and Owen, A. (2020) Prioritisation of potential anti-SARS-CoV-2 drug repurposing opportunities based on ability to achieve adequate target site concentrations derived from their established human pharmacokinetics. medRxiv, 2020.04.16.20068379, https://www.medrxiv.org/ content/10.1101/2020.04.16.20068379v1.

(74) M Nissink, J. W., and Blackburn, S. (2014) Quantification of frequent-hitter behavior based on historical high-throughput screening data. Future Med. Chem. 6 (10), 1113-1126.

(75) Aldrich, C., Bertozzi, C., Georg, G. I., Kiessling, L., Lindsley, C., Liotta, D., Merz, K. M., Schepartz, A., and Wang, S. (2017) The Ecstasy and Agony of Assay Interference Compounds. J. Chem. Inf. Model. 57 (3), 387-390.

(76) Aggregator Advisor. http://advisor.bkslab.org.

(77) Sparks, H., Nair, G., Castellanos-Gonzalez, A., and White, A. C., Jr. (2015) Treatment of Cryptosporidium: What We Know, Gaps, and the Way Forward. Curr. Trop Med. Rep 2 (3), 181-187.

(78) Clerici, M., Trabattoni, D., Pacel, M., Biasin, M., and Rossignol, J. F. (2011) The anti-infective Nitazoxanide shows strong immumodulating effects. J. Immunol. 186, 155.21.

(79) Petersen, T., Lee, Y. J., Osinusi, A., Amorosa, V. K., Wang, C., Kang, M., Matining, R., Zhang, X., Dou, D. N., Umbleja, T., Kottilil, S., and Peters, M. G. (2016) Interferon Stimulated Gene Expression in HIV/HCV Coinfected Patients Treated with Nitazoxanide/ Peginterferon-Alfa-2a and Ribavirin. AIDS Res. Hum. Retroviruses 32 (7), 660-667.

(80) Elazor, M., Liu, M., McKenna, S., Liu, P., Gehrig, E. A., Elfert, A., Puglisi, J., Rossignol, J. F., and Glenn, J. S. (2008) Nitazoxanide (Ntz) Is an Inducer Eif2a and Pkr Phosphorylation. Hepatology 48 (4), 1151a-1151a.

(81) Elazar, M., Liu, M., Mckenna, S. A., Liu, P., Gehrig, E. A., Puglisi, J. D., Rossignol, J. F., and Glenn, J. S. (2009) The AntiHepatitis C Agent Nitazoxanide Induces Phosphorylation of Eukaryotic Initiation Factor 2 alpha Via Protein Kinase Activated by Double-Stranded RNA Activation. Gastroenterology 137 (5), $1827-1835$.

(82) Ashiru, O., Howe, J. D., and Butters, T. D. (2014) Nitazoxanide, an antiviral thiazolide, depletes ATP-sensitive intracellular Ca2+ stores. Virology 462, 135-148.

(83) Sekiba, K., Otsuka, M., Ohno, M., Yamagami, M., Kishikawa, T., Suzuki, T., Ishibashi, R., Seimiya, T., Tanaka, E., and Koike, K. (2019) Inhibition of HBV Transcription From cccDNA With
Nitazoxanide by Targeting the HBx-DDB1 Interaction. Cell Mol. Gastroenter. 7 (2), 297-312.

(84) Jasenosky, L. D., Cadena, C., Mire, C. E., Borisevich, V., Haridas, V., Ranjbar, S., Nambu, A., Bavari, S., Soloveva, V., Sadukhan, S., Cassell, G. H., Geisbert, T. W., Hur, S., and Goldfeld, A. E. (2019) The FDA-Approved Oral Drug Nitazoxanide Amplifies Host Antiviral Responses and Inhibits Ebola Virus. iScience 19, 12791290.

(85) Li, Z., Brecher, M., Deng, Y. Q., Zhang, J., Sakamuru, S., Liu, B. B., Huang, R. L., Koetzner, C. A., Allen, C. A., Jones, S. A., Chen, H., Zhang, N. N., Tian, M., Gao, F. S., Lin, Q. S., Banavali, N., Zhou, J., Boles, N., Xia, M. H., Kramer, L. D., Qin, C. F., and Li, H. M. (2017) Existing drugs as broad-spectrum and potent inhibitors for Zika virus by targeting NS2B-NS3 interaction. Cell Res. 27 (8), 1046-1064.

(86) Piacentini, S., La Frazia, S., Riccio, A., Pedersen, J. Z., Topai, A., Nicolotti, O., Rossignol, J. F., and Santoro, M. G. (2018) Nitazoxanide inhibits paramyxovirus replication by targeting the Fusion protein folding: role of glycoprotein-specific thiol oxidoreductase ERp57. Sci. Rep. 8, 14.

(87) Hong, S. K., Kim, H. J., Song, C. S., Choi, I. S., Lee, J. B., and Park, S. Y. (2012) Nitazoxanide suppresses IL-6 production in LPSstimulated mouse macrophages and TG-injected mice. Int. Immunopharmacol. 13 (1), 23-27.

(88) McDonald, L. C., Gerding, D. N., Johnson, S., Bakken, J. S., Carroll, K. C., Coffin, S. E., Dubberke, E. R., Garey, K. W., Gould, C. V., Kelly, C., Loo, V., Shaklee Sammons, J., Sandora, T. J., and Wilcox, M. H. (2018) Clinical Practice Guidelines for Clostridium difficile Infection in Adults and Children: 2017 Update by the Infectious Diseases Society of America (IDSA) and Society for Healthcare Epidemiology of America (SHEA). Clin. Infect. Dis. 66 (7), e1-e48.

(89) Rossignol, J. F., Hidalgo, H., Feregrino, M., Higuera, F., Gomez, W. H., Romero, J. L., Padierna, J., Geyne, A., and Ayers, M. S. (1998) A double-'blind' placebo-controlled study of nitazoxanide in the treatment of cryptosporidial diarrhoea in AIDS patients in Mexico. Trans. R. Soc. Trop. Med. Hyg. 92 (6), 663-6.

(90) Stockis, A., Deroubaix, X., Lins, R., Jeanbaptiste, B., Calderon, P., and Rossignol, J. F. (1996) Pharmacokinetics of nitazoxanide after single oral dose administration in 6 healthy volunteers. Int. J. Clin. Pharmacol. Ther. 34 (8), 349-51.

(91) Stockis, A., De Bruyn, S., Gengler, C., and Rosillon, D. (2002) Nitazoxanide pharmacokinetics and tolerability in man during 7 days dosing with 0.5 and $1 \mathrm{~g}$ b.i.d. Int. J. Clin. Pharmacol. Ther. 40, 221-7. (92) Rajoli, R. K. R., Pertinez, H., Arshad, U., Box, H., Tatham, L., Curley, P., Neary, M., Sharp, J., Liptrott, N. J., Valentijn, A., David, C., Rannard, S. P., Aljayyoussi, G., Pennington, S. H., Hill, A., Boffito, M., Ward, S. A., Khoo, S. H., Bray, P. G., O’Neill, P. M., Hong, W. D., Biagini, G., and Owen, A. (2020) Dose prediction for repurposing nitazoxanide in SARS-CoV-2 treatment or chemoprophylaxis. Br. J. Clin. Pharmacol., 1-11.

(93) International Clinical Trials Registry Platform (ICTRP) Search Portal. https://www.who.int/ictrp/search/en/.

(94) Buchieri, M. V., Cimino, M., Rebollo-Ramirez, S., Beauvineau, C., Cascioferro, A., Favre-Rochex, S., Helynck, O., Naud-Martin, D., Larrouy-Maumus, G., Munier-Lehmann, H., and Gicquel, B. (2017) Nitazoxanide Analogs Require Nitroreduction for Antimicrobial Activity in Mycobacterium smegmatis. J. Med. Chem. 60 (17), 7425-7433.

(95) Ballard, T. E., Wang, X., Olekhnovich, I., Koerner, T., Seymour, C., Hoffman, P. S., and Macdonald, T. L. (2010) Biological activity of modified and exchanged 2-amino-5-nitrothiazole amide analogues of nitazoxanide. Bioorg. Med. Chem. Lett. 20 (12), 3537-3539.

(96) Pankuch, G. A., and Appelbaum, P. C. (2006) Activities of tizoxanide and nitazoxanide compared to those of five other thiazolides and three other agents against anaerobic species. Antimicrob. Agents Chemother. 50 (3), 1112-1117.

(97) Nepali, K., Lee, H.-Y., and Liou, J.-P. (2019) Nitro-GroupContaining Drugs. J. Med. Chem. 62 (6), 2851-2893.

(98) Stachulski, A. Personal Communication. 2020. 
(99) Praveen Rao, P. N., Amini, M., Li, H., Habeeb, A. G., and Knaus, E. E. (2003) Design, Synthesis, and Biological Evaluation of 6Substituted-3-(4-methanesulfonylphenyl)-4-phenylpyran-2-ones: A Novel Class of Diarylheterocyclic Selective Cyclooxygenase-2 Inhibitors. J. Med. Chem. 46 (23), 4872-4882.

(100) Stachulski, A. V., Baillie, T. A., Kevin Park, B., Scott Obach, R., Dalvie, D. K., Williams, D. P., Srivastava, A., Regan, S. L., Antoine, D. J., Goldring, C. E. P., Chia, A. J. L., Kitteringham, N. R., Randle, L. E., Callan, H., Castrejon, J. L., Farrell, J., Naisbitt, D. J., and Lennard, M. S. (2013) The Generation, Detection, and Effects of Reactive Drug Metabolites. Med. Res. Rev. 33 (5), 985-1080.

(101) Obach, R. S., Kalgutkar, A. S., Ryder, T. F., and Walker, G. S. (2008) In Vitro Metabolism and Covalent Binding of EnolCarboxamide Derivatives and Anti-Inflammatory Agents Sudoxicam and Meloxicam: Insights into the Hepatotoxicity of Sudoxicam. Chem. Res. Toxicol. 21 (9), 1890-1899.

(102) Beauchamp, L. M., Orr, G. F., de Miranda, P., Bumette, T., and Krenitsky, T. A. (1992) Amino Acid Ester Prodrugs of Acyclovir. Antiviral Chem. Chemother. 3 (3), 157-164.

(103) Guo, A., Hu, P., Balimane, P. V., Leibach, F. H., and Sinko, P. J. (1999) Interactions of a Nonpeptidic Drug, Valacyclovir, with the Human Intestinal Peptide Transporter (hPEPT1) Expressed in a Mammalian Cell Line. J. Pharmacol. Exp. Ther. 289 (1), 448-454.

(104) Bobrowski, T., Chen, L., Eastman, R. T., Itkin, Z., Shinn, P., Chen, C., Guo, H., Zheng, W., Michael, S., Simeonov, A., Hall, M. D., Zakharov, A. V., and Muratov, E. N. (2020) Discovery of Synergistic and Antagonistic Drug Combinations against SARS-CoV-2 In Vitro. bioRxiv, 2020.06.29.178889, https://www.biorxiv.org/content/10. $1101 / 2020.06 .29 .178889 \mathrm{v} 1$.

(105) COVID-19 Drug Interactions Checkers. https://www. covid19-druginteractions.org/checker.

(106) Hydroxychloroquine vs Nitazoxanide in Patients With COVID-19. https://ClinicalTrials.gov/show/NCT04341493.

(107) Efficacy and Safety of Nitazoxanide $600 \mathrm{mg}$ TID for the Treatment of Hospitalized Patients With COVID-19. https:// clinicaltrials.gov/ct2/show/NCT04423861. 